\title{
The Role of Myeloperoxidase in Biomolecule Modification, Chronic Inflammation, and Disease
}

\author{
Michael J. Davies and Clare L. Hawkins
}

\begin{abstract}
Significance: The release of myeloperoxidase (MPO) by activated leukocytes is critical in innate immune responses. MPO produces hypochlorous acid $(\mathrm{HOCl})$ and other strong oxidants, which kill bacteria and other invading pathogens. However, MPO also drives the development of numerous chronic inflammatory pathologies, including atherosclerosis, neurodegenerative disease, lung disease, arthritis, cancer, and kidney disease, which are globally responsible for significant patient mortality and morbidity.

Recent Advances: The development of imaging approaches to precisely identify the localization of MPO and the molecular targets of $\mathrm{HOCl}$ in vivo is an important advance, as typically the involvement of $\mathrm{MPO}$ in inflammatory disease has been inferred by its presence, together with the detection of biomarkers of $\mathrm{HOCl}$, in biological fluids or diseased tissues. This will provide valuable information in regard to the cell types responsible for releasing MPO in vivo, together with new insight into potential therapeutic opportunities.

Critical Issues: Although there is little doubt as to the value of MPO inhibition as a protective strategy to mitigate tissue damage during chronic inflammation in experimental models, the impact of long-term inhibition of MPO as a therapeutic strategy for human disease remains uncertain, in light of the potential effects on innate immunity.

Future Directions: The development of more targeted MPO inhibitors or a treatment regimen designed to reduce MPO-associated host tissue damage without compromising pathogen killing by the innate immune system is therefore an important future direction. Similarly, a partial MPO inhibition strategy may be sufficient to maintain adequate bacterial activity while decreasing the propagation of inflammatory pathologies. Antioxid. Redox Signal. 32, 957-981.
\end{abstract}

Keywords: myeloperoxidase, hypohalous acid, oxidation, inflammation, oxidative stress

\section{Introduction}

$\mathbf{M}$ YELOPEROXIDASE (MPO) is a key element of the innate immune system and is released primarily by neutrophils to provide defence against invading pathogens. MPO comprises about $5 \%$ of the dry mass of the neutrophil and is contained predominantly within the lysosomal azurophilic granules. On neutrophil activation, fusion of lysosomes with phagosomes results in release of MPO, while assembly of an NADPH oxidase complex on the internal membrane surface results in the production of superoxide anions $\left(\mathrm{O}_{2}^{-\bullet}\right)$, which rapidly dismutate to form hydrogen peroxide $\left(\mathrm{H}_{2} \mathrm{O}_{2}\right)$. MPO catalyzes the reaction of $\mathrm{H}_{2} \mathrm{O}_{2}$ with chloride ions $\left(\mathrm{Cl}^{-}\right)$to form hypochlorous acid $(\mathrm{HOCl})$, which facilitates the destruction of microbes contained within the phagolysosome $(170,292)$. However, some MPO is also released extracellularly, where the misplaced production of $\mathrm{HOCl}$ can promote host tissue damage and the development of disease. This is particularly significant during chronic inflammation, owing to the excessive leukocyte infiltration and activation $(50,265)$.

Exposure of neutrophils to pathogens, and inflammatory mediators (e.g., cytokines, chemokines, complement proteins, or oxidants such as $\mathrm{HOCl}$ ), also triggers the release of neutrophil extracellular traps (NETs) $(27,70)$. NETs are released by a pathway termed "NETosis," and consist of a

Department of Biomedical Sciences, Panum Institute, University of Copenhagen, Copenhagen N, Denmark. 
mesh of extracellular DNA, complexed with histones and neutrophil granule proteins, including MPO (261). In addition to its presence on the NET structure, MPO also plays a critical role in triggering neutrophils to undergo NETosis (160). NET-bound MPO retains its activity and can promote bacterial cell killing, or promote tissue injury in the presence of $\mathrm{H}_{2} \mathrm{O}_{2}$ (181). There is increasing evidence that NETs play a causal role in the development of some inflammatory diseases [reviewed in Bonaventura et al. (22)], providing an additional pathway by which MPO could contribute pathologically.

Although $\mathrm{HOCl}$ production is believed to be essential for the efficient removal of pathogens, there is little doubt that this and other MPO-derived, reactive species can initiate oxidative tissue damage and cellular dysfunction, and thereby promote disease progression. This is supported by evidence for the presence of MPO, together with specific biomarkers for $\mathrm{HOCl}$-mediated damage, particularly 3chlorotyrosine (Cl-Tyr), in diseased tissue and inflammatory fluids, which implicates this peroxidase in numerous inflammatory pathologies, as shown in Table 1. Genetic polymorphisms, particularly the MPO-463G $>$ A allele, located in the promoter region of the MPO gene, may also play a role in disease, by influencing MPO transcription levels. This polymorphism has been studied in the context of different diseases and, in general, individuals with the more common G-allele have higher levels of MPO gene expression, and a

Table 1. Diseases Associated with a Pathological Role OF MYELOPEROXIDASE

\begin{tabular}{lc}
\hline Disease & References \\
\hline Cardiovascular disease/atherosclerosis & $(49,171,257,308)$ \\
Myocardial infarction & $(163,217)$ \\
Vascular dysfunction & $(60,151,274)$ \\
Lipoprotein modification & $(53,150,171)$ \\
Atrial fibrillation & $(139,216)$ \\
Plaque rupture & $(240,247)$ \\
Hypertension & $(131,267)$ \\
Abdominal aortic aneurysm & $(128)$ \\
Neurodegenerative disease & $(196,201)$ \\
Alzheimer's disease & $(80,258)$ \\
Parkinson's disease & $(44,112)$ \\
Multiple sclerosis & $(78,79,167)$ \\
Stroke & $(45,245,300)$ \\
Kidney disease & $(149)$ \\
Chronic kidney disease & $(129,138)$ \\
Glomerulonephritis & $(177)$ \\
Respiratory disease & $(32,111)$ \\
Asthma & $(120,266,268)$ \\
Cystic fibrosis & $(176)$ \\
Chronic obstructive & \\
pulmonary disease & $(236,278)$ \\
Other diseases & $(246)$ \\
Rheumatoid arthritis & $(239)$ \\
Systemic lupus erythematosus & $(6,277)$ \\
Autoimmune disease & $(210)$ \\
Metabolic syndrome/obesity & $(40,75)$ \\
Type 2 diabetes & $(104)$ \\
Nonalcoholic steatohepatitis & $(38)$ \\
Inflammatory bowel disease/colitis & \\
Cancer/carcinogenesis & \\
Noninfectious disease & \\
Aging & $(62,283)$ \\
\hline & \\
& \\
\hline
\end{tabular}

greater incidence of disease development compared with those with the A-allele $(167,213)$, although in terms of cancer development, the data are inconsistent [reviewed in Yang et al. (295)].

In this article, we focus on the role of MPO in chronic inflammation and disease, rather than in host defence. We provide an overview of the enzymology, substrate specificity, and oxidant production by MPO, and discuss some examples of how the targeting and modification of specific tissues and biological substrates can modulate cellular function in a detrimental manner to promote the development of inflammatory disease. We also review potential approaches to prevent these damaging reactions, which may have therapeutic value in chronic inflammatory diseases.

\section{Enzymology of MPO and Oxidant Production}

\section{Structure of MPO}

Mature MPO is a highly cationic (positively charged, $\mathrm{pI}$ $\sim 10$ ) dimeric protein with a mass of $\sim 146 \mathrm{kDa}$. The two dimers are identical and functionally independent. Each molecule consists of two monomer units ( $73 \mathrm{kDa}$ each) joined by a single disulfide between the Cys 153 residues. Each monomer comprises a heavy (58.5 kDa, 467 amino acids) and light chain (14.5 kDa, 106 amino acids) (64), with the former having multiple glycosylation sites. The heavy chains contain a modified iron protoporphyrin IX derivative, which is the active site, with this being located in a deep cleft (302). This restricts access of the iron atom to $\mathrm{H}_{2} \mathrm{O}_{2}$ and a number of small negatively charged anions (21). A second hydrophobic binding pocket is present at the entrance to the distal heme cavity, with this being the site of oxidation of large substrates via the peroxidase cycle (103).

The structure of MPO (and other human peroxidases) has been reviewed (72). The proximal histidine ligand is a key regulator of the redox properties of the heme iron and is hydrogen bonded to an asparagine, which acts as a hydrogen bond acceptor and helps stabilize the resting (ferric, $\mathrm{Fe}^{3+}$ ) form of the enzyme (72). The redox properties of the heme are markedly affected by a sulfonium ion (covalent) linkage between the heme and Met-243 (301). This withdraws electron density from the heme, due to its positive charge, and distorts the heme from planarity. A distal histidine ligand is also present and is believed to act as an acid/base catalyst with a nearby arginine via a hydrogen-bonded network, to polarize the -O-O- bond of $\mathrm{H}_{2} \mathrm{O}_{2}(64)$, with cleavage of this bond initiating the catalytic cycles of the enzyme (72). The importance of this hydrogen bonding network is indicated by its conservation in other peroxidases (72). Each enzyme also has a conserved asparagine residue adjacent to the distal histidine that appears to align this via coordination with a bound $\mathrm{Ca}^{2+}(72)$. Crystal structure data indicate that halide substrates bind within this cavity $\sim 3.5 \AA$ from the $\mathrm{N}^{\varepsilon}$ atom of the distal histidine $(20,64)$, with this favored at acidic $\mathrm{pH}$ values by protonation of the distal histidine and electrostatic interactions (107).

\section{Catalytic cycles of MPO}

$\mathrm{H}_{2} \mathrm{O}_{2}$ reacts with ferric MPO via a two-electron reaction to generate Compound I [an oxy-ferryl $\left(\mathrm{Fe}^{\mathrm{IV}}=\mathrm{O}\right)$ heme species with a porphyrin $\pi$ radical-cation], and a molecule of $\mathrm{H}_{2} \mathrm{O}$. 
FIG. 1. Generation and reactions of redox intermediates of MPO. $\mathrm{RH}_{2}$ denotes a classic organic peroxidase substrate; other species also undergo one-electron oxidation by Compound I and Compound II. MPO, myeloperoxidase. Adapted from Nussbaum et al. (173). Color images are available online.

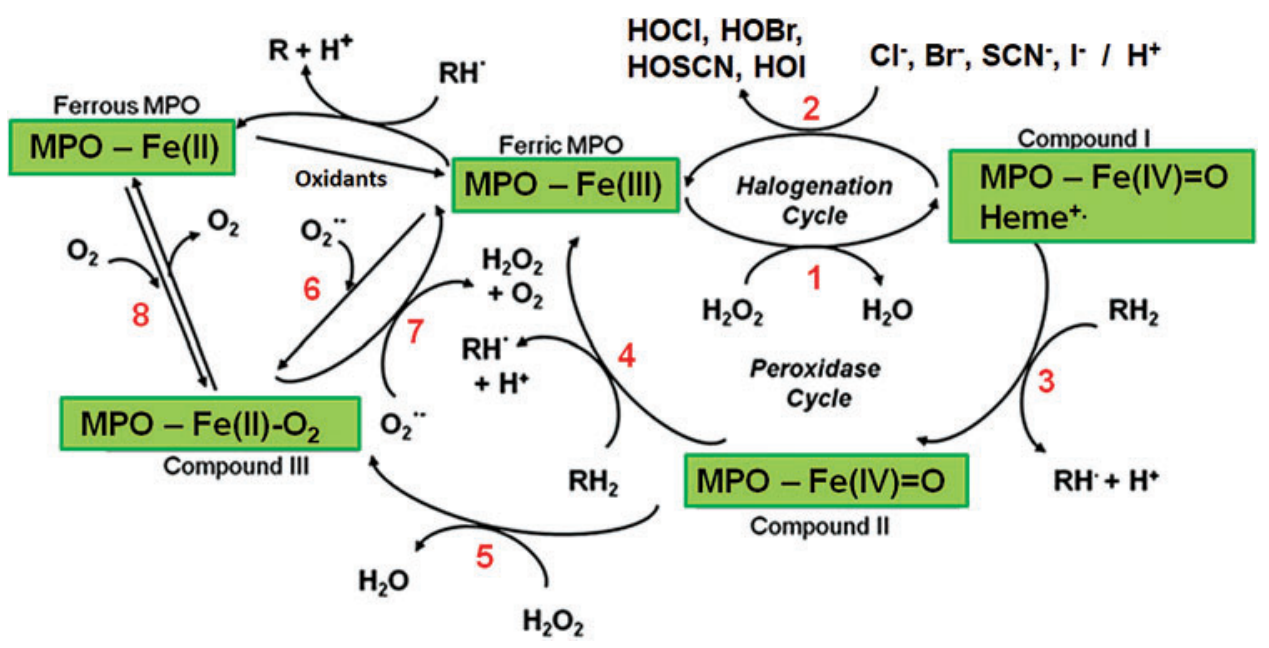

Compound I is then converted back to the ferric form via two independent and discrete pathways. The first involves direct, two-electron reduction of Compound I species by halide $\left(\mathrm{Cl}^{-}\right.$, bromide ion $\left[\mathrm{Br}^{-}\right]$, iodide ion $\left[\mathrm{I}^{-}\right]$) and pseudohalide (thiocyanate ion $\left.\left[\mathrm{SCN}^{-}\right]\right)$anions. This is commonly termed "the halogenation cycle" and results in the formation of hypohalous acids: $\mathrm{HOCl}, \mathrm{HOBr}$ (hypobromous acid), HOI (hypoiodous acid), and hypothiocyanous acid ( $\mathrm{HOSCN})$. The second pathway involves two sequential one-electron reduction reactions, which involve a second enzyme intermediate, Compound II [an oxy-ferryl $\left(\mathrm{Fe}^{\mathrm{IV}}=\mathrm{O}\right)$ heme species]. Compound II then undergoes a second one-electron reduction to give the ferric species. This second pathway is usually termed "the peroxidase cycle." These processes and the corresponding second-order rate constants are summarized in Figure 1 and Table 2. A further intermediate, Compound III, can be formed via reaction of the ferric state with superoxide radical anion $\left(\mathrm{O}_{2}{ }^{--}\right)$, or via one-electron reduction of the ferric state of the enzyme to the ferrous $\left(\mathrm{Fe}^{2+}\right)$ form and subsequent $\mathrm{O}_{2}$ addition. These reactions allow $\mathrm{O}_{2}{ }^{\bullet-}$ dependent catalytic activities of MPO (119).

\section{Substrate specificity: halogenation cycle}

As a result of the heme ring distortion and the sulfonium linkage, Compound I of MPO has a high reduction potential for both the Compound I/native enzyme and the Compound I/ Compound II couples (301). The Compound II/native enzyme couple has a lower value. These high values allow MPO to oxidize a wide range of substrates via the halogenation and peroxidase cycles, although the potentials vary with $\mathrm{pH}$, and impose thresholds on substrate oxidation (235).

Unlike Compounds I and II, Compound III is poorly reactive and is often considered a catalytic "dead-end," although it can induce slow (one-electron) oxidation of ascorbate and paracetamol (acetaminophen) (153) and also

Table 2. Selected Apparent Second-Order Rate Constants $\left(M^{-1} \cdot \mathrm{s}^{-1}\right)$ For the Reactions Listed in the Halogenation and Peroxidase Cycles of Myeloperoxidase, Shown in Figure 1

\section{Reaction}

No. (Fig. 1)

Reaction description

Rate constant

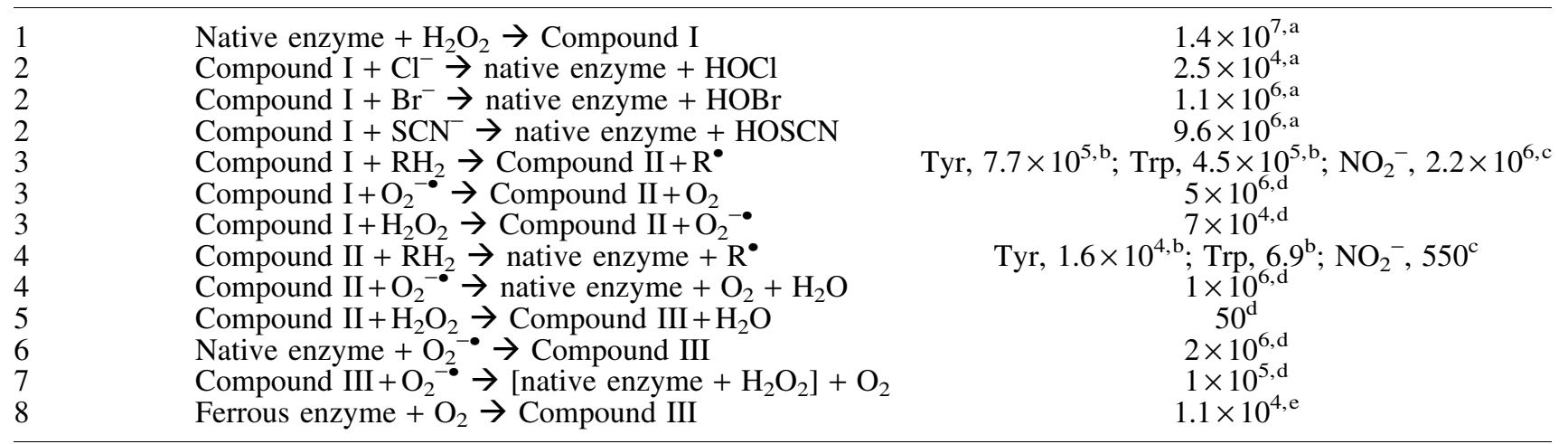

${ }^{\mathrm{a}}$ Measured at $\mathrm{pH} 7.0$ and $15^{\circ} \mathrm{C}$ [reviewed in Furtmuller et al. (72)].

${ }^{\mathrm{b}}$ Measured at $\mathrm{pH} 7.0$ and $25^{\circ} \mathrm{C}(109)$.

${ }^{\mathrm{c}}$ Measured at $\mathrm{pH} 7.0$ [reviewed in Arnhold et al. (9)].

${ }^{\mathrm{d}}$ From Winterbourn et al. (291).

${ }^{\mathrm{e}}$ Measured at $\mathrm{pH} 7.0$ and $25^{\circ} \mathrm{C}(110)$.

$\mathrm{Br}^{-}$, bromide ion; $\mathrm{Cl}^{-}$, chloride ion; $\mathrm{H}_{2} \mathrm{O}_{2}$, hydrogen peroxide; $\mathrm{HOBr}$, hypobromous acid; $\mathrm{HOCl}$, hypochlorous acid; $\mathrm{HOSCN}$, hypothiocyanous acid; $\mathrm{SCN}^{-}$, thiocyanate ions. 
$\mathrm{O}_{2}{ }^{\bullet-}$ thereby regenerating ferric MPO and producing $\mathrm{H}_{2} \mathrm{O}_{2}$ and $\mathrm{O}_{2}$. MPO can therefore act in a similar manner to a superoxide dismutase (SOD), and the concentration of $\mathrm{O}_{2}^{\bullet-}$ can modulate the activity of MPO (119). Computational modeling suggests that within the neutrophil phagosome (where MPO concentrations have been calculated as $\sim 1 \mathrm{mM}$ ), most of the $\mathrm{O}_{2}{ }^{\bullet-}$ produced by NADPH oxidase is consumed via this SOD-like activity, and that efficient recycling of Compound III by $\mathrm{O}_{2}^{\bullet-}$ ensures that phagosomal $\mathrm{HOCl}$ production is not constrained (291). However, when MPO concentrations and $\mathrm{H}_{2} \mathrm{O}_{2}$ fluxes are low, and turnover of the ferric enzyme is rate limiting, Compound III formation can constrain MPO activity (126).

Although $\mathrm{H}_{2} \mathrm{O}_{2}$ is essential for the catalytic cycles of the enzyme, high concentrations can also inhibit these activities, as it can also act as a competitive substrate for Compound I and Compound II (to give the poorly reactive Compound III), and by inducing irreversible enzyme inactivation $(72,126)$. Therefore, in the absence of substrates, MPO exhibits catalase-like activity (127). With high $\mathrm{H}_{2} \mathrm{O}_{2}$ fluxes, where reaction of Compound I with $\mathrm{H}_{2} \mathrm{O}_{2}$ results in Compound II accumulation, $\mathrm{O}_{2}{ }^{\bullet-}$ appears to maintain chlorinating activity by recycling Compound II to the ferric form $(72,126)$.

The ability of MPO to oxidize $\mathrm{Cl}^{-}$with a high rate constant is unique among the peroxidase family, although this anion is not the most favored substrate, as the second-order rate constants for reaction of Compound I with anions reflect the reduction potentials of the various potential substrates, and decrease down the series $\mathrm{SCN}^{-}>\mathrm{I}^{-}>\mathrm{Br}^{-}>\mathrm{Cl}^{-}$. The lower twoelectron reduction potentials of Compound I of other peroxidases limit rapid oxidation to $\mathrm{SCN}^{-}, \mathrm{I}^{-}$, and $\mathrm{Br}^{-}$, and not $\mathrm{Cl}^{-}$.

With typical physiological plasma concentrations of these anions $\left(\mathrm{Cl}^{-} \sim 100\right.$ to $150 \mathrm{mM}, \mathrm{Br}^{-} 20$ to $100 \mu M, \mathrm{SCN}^{-} 20$ to $150 \mu M, \mathrm{I}^{-}<0.1$ to $\left.1 \mu M\right)$, MPO generates predominantly $\mathrm{HOCl}$ and HOSCN (263), with only low levels of $\mathrm{HOBr}$, and minimal HOI formed. It should, however, be noted that this conclusion is dependent on the specific environment, with altered yields of oxidants produced on supplementation/ depletion of these anions. Specificity constants and $\mathrm{K}_{\mathrm{m}}$ values for each of these anions have been reported $(262,263)$. The species formed are also $\mathrm{pH}$ dependent, with $\mathrm{HOBr}$ production by MPO reported to be enhanced at $\mathrm{pH}$ values $>7$, such that at $\mathrm{pH} 7.8$, $\mathrm{HOBr}$ may account for up to $40 \%$ of the $\mathrm{H}_{2} \mathrm{O}_{2}$ consumed by MPO (223). The rate of oxidation is also significantly enhanced at acidic $\mathrm{pH}(9)$, due to an increased affinity of the anions for the protonated distal histidine (107). This effect is most pronounced for $\mathrm{Cl}^{-}$, which may indicate that this anion, but not others, may have direct access to the oxyferryl heme center at low $\mathrm{pH}$ values (72). There has been debate as to whether free $\mathrm{HOCl}$ is formed by MPO, with evidence presented for direct chlorination by an intermediate Compound $\mathrm{I}^{-\mathrm{Cl}^{-}}$complex at low $\mathrm{pH}$ (154). However, the chlorination of large proteins and other targets by MPO$\mathrm{H}_{2} \mathrm{O}_{2}-\mathrm{Cl}^{-}$suggests that freely diffusible species must be generated, a conclusion supported by studies that quantified $\mathrm{HOCl}$ production within neutrophil phagolysosomes, using a rhodamine-based fluorescent probe (3).

\section{Substrate specificity: peroxidase cycle}

The MPO peroxidase cycle generates radicals from organic substrates via one-electron oxidation by Compounds I and II, and also oxidizes some radicals, including $\mathrm{O}_{2}{ }^{\bullet-}$, nitric oxide radical $\left(\mathrm{NO}^{\bullet}\right)$, and nitroxides $(2,114,126,204)$, to nonradical products. Although reaction of $\mathrm{NO}^{\bullet}$ with Compounds I and II is facile, consumption of $\mathrm{NO}^{\bullet}$ in plasma at physiologically relevant fluxes (steady state $<1 \mu M$ ) is likely to occur predominantly via reaction with long-lived radicals (e.g., tyrosyl and ascorbyl) generated via the peroxidase cycle (56). Nitrite ion $\left(\mathrm{NO}_{2}^{-}\right)$reacts with Compounds I and II to give nitrogen dioxide radical $\left(\mathrm{NO}_{2}{ }^{\circ}\right)$ (264). A small but significant fraction of $\mathrm{NO}_{2}{ }^{-}$has been reported to be oxidized to a species that can induce hydroxylation as well as nitration, a property shared by peroxynitrous acid $(\mathrm{ONOOH})$. In contrast to free $\mathrm{ONOOH}$, the $\mathrm{MPO}-\mathrm{H}_{2} \mathrm{O}_{2-}$ $\mathrm{NO}_{2}{ }^{-}$system appears to induce hydroxylation only at acidic $\mathrm{pH}$, and $\mathrm{CO}_{2}$ does not enhance nitration, consistent with an enzyme-bound intermediate (25). ONOOH rapidly converts MPO Compounds I and III, to Compound II. Compound II does not appear to oxidize $\mathrm{ONOOH}$, despite this being thermodynamically favorable (71). The peroxidase reactions of Compound I occur in competition with the halogenation cycle and hence are affected by the concentration of these species relative to the halide/pseudohalide ions.

Physiologically relevant organic peroxidase substrates for MPO include both endogenous compounds (e.g., Tyr, ascorbate, steroidal hormones, and urate) and xenobiotics and drugs. The range of compounds is extensive due to the high reduction potential of Compound I, and to a lesser extent Compound II. Some substrates can react readily with Compound I, but not Compound II (i.e., species with reduction potentials between those for Compound I/Compound II and Compound II/ferric enzyme; often termed "poor" peroxidase substrates), with this resulting in an accumulation of Compound II and arrest of the catalytic cycle. Kinetic factors can also influence peroxidase cycle turnover, with rate constants for reaction of substrates with Compound II often significantly lower than with Compound I (155). The halogenation cycle typically occurs more rapidly than the peroxidase cycle, resulting in higher yields of hypohalous acids than radical species, although this is $\mathrm{pH}$ dependent (155).

Some radicals generated by the peroxidase cycle can react with the heme moiety and result in enzyme inactivation; this is the mode of action of a number of MPO inhibitors [e.g., thioxanthines (253)]. Radicals may also reduce ferric MPO to ferrous MPO and hence yield Compound III in the presence of $\mathrm{O}_{2}$; this occurs, for example, during the metabolism of hydroquinone (125) and hydrazides (122). Reaction with the enzyme may also generate protein-derived radicals, via hydrogen atom abstraction or addition to aromatic amino acids (226). Radicals may also diffuse from the active site and damage other biomolecules such as lipids (116) and proteins (99).

\section{Reactivity of MPO-Derived Oxidants}

\section{Reactions of $\mathrm{HOCl}$ and $\mathrm{N}$-chloramines}

$\mathrm{HOCl}$ is produced under both physiological and pathological conditions, as evidenced by the detection of chlorinated biomarkers, particularly Cl-Tyr, in inflammatory fluids and diseased tissues (Table 1). $\mathrm{HOCl}$ is a powerful oxidant and chlorinating agent, and exists in equilibrium with its conjugate base, hypochlorite $\left[{ }^{-} \mathrm{OCl}, \mathrm{pK}_{\mathrm{a}} 7.59\right.$ (166)] at physiological $\mathrm{pH}$. $\mathrm{HOCl}$ reacts rapidly with nucleophiles, and 


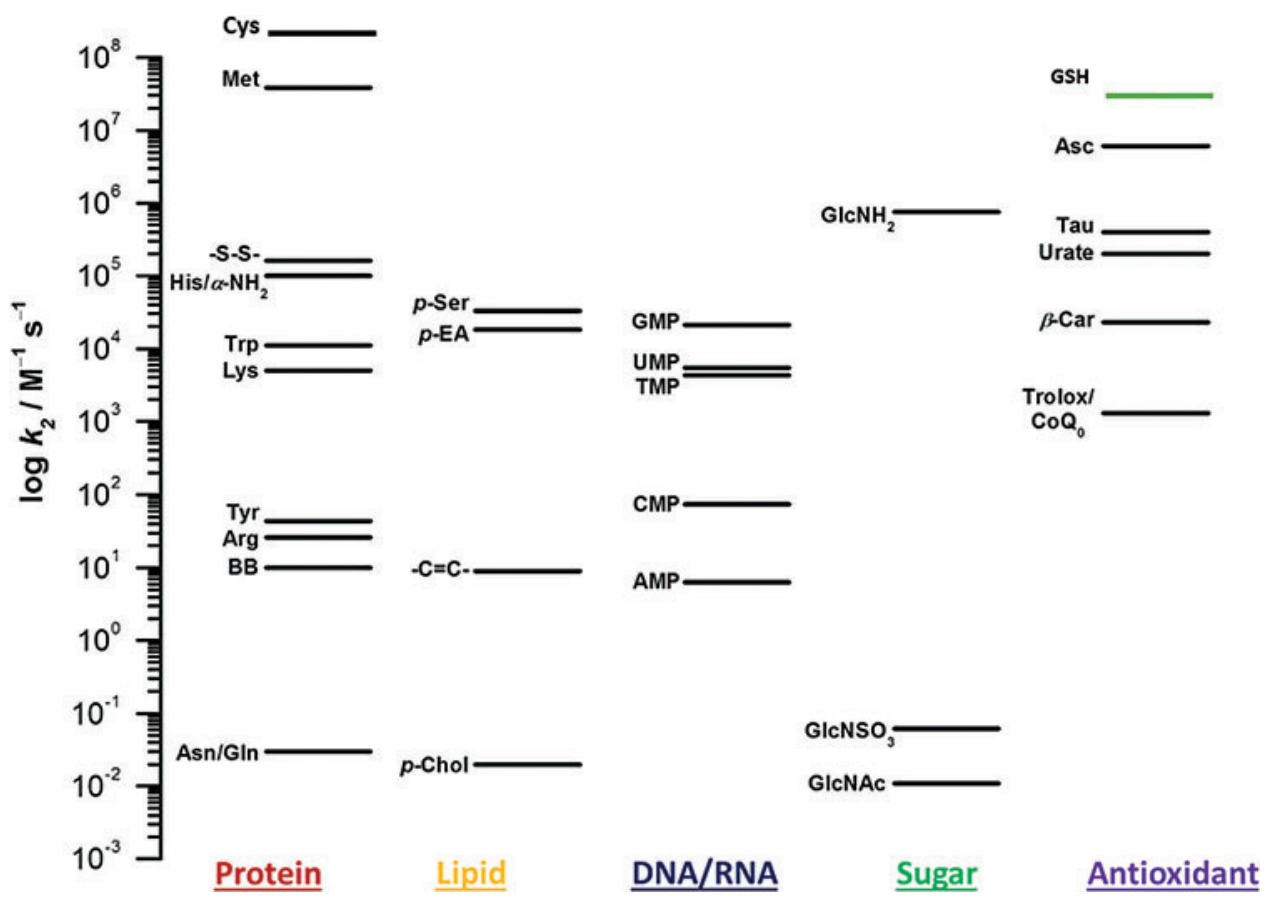

FIG. 2. Plot summarizing the second-order rate constants (on a log scale) for the reactions of HOCl with model compounds of protein, lipid, and carbohydrate components, nucleobases, and antioxidants [reviewed in Pattison and Davies (186)]. The majority of the rate constants were acquired in phosphate-buffered solutions at $\mathrm{pH} 6.8-7.5$ and $20^{\circ} \mathrm{C}-25^{\circ} \mathrm{C}(65$, $183,188,197,198,207,289)$; however, that for $\beta$-carotene was determined in a detergent solution at $\mathrm{pH} 4.5(4) . \alpha-\mathrm{NH}_{2}, \alpha$-amino group; $\beta$-Car, $\beta$-carotene; Asc, ascorbate; $\mathrm{BB}$, backbone amides; $-\mathrm{C}=\mathrm{C}$-, double bond; $\mathrm{CoQ}_{0}$, ubiquinol-0; GlcNAc, $N$-acetylated glucosamine; $\mathrm{GlcNH}_{2}$, glucosamine; $\mathrm{GlcNSO}_{3}, \mathrm{~N}$-sulfated glucosamine; $\mathrm{HOCl}$, hypochlorous acid; $p$-Chol, phosphoryl-choline; p-EA, phosphoryl-ethanolamine; $p$-Ser, phosphoryl-Ser; -S-S-, disulfide bond. Color images are available online.

especially those with sulfur or nitrogen atoms (e.g., thiols, thioethers, and amines). Selected second-order rate constants, and products generated by $\mathrm{HOCl}$, are shown in Figures 2 and 3 and Table 3.

Cys and Met residues in proteins and glutathione (GSH) are key targets of $\mathrm{HOCl}$ (238). Oxidation of Cys yields a

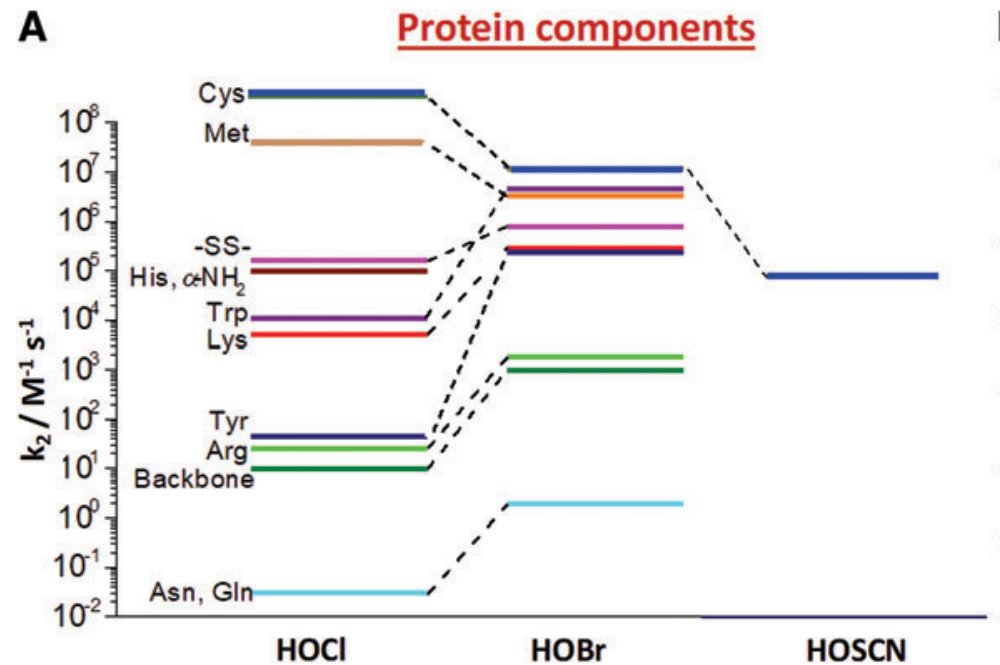

sulfenyl chloride ( $\mathrm{RS}-\mathrm{Cl})$, which reacts rapidly with excess thiol to give the disulfide, or $\mathrm{H}_{2} \mathrm{O}$ to yield sulfenic ( $\mathrm{RSOH}$ ), sulfinic $\left(\mathrm{RSO}_{2} \mathrm{H}\right)$, and sulfonic acids $\left(\mathrm{RSO}_{3} \mathrm{H}\right.$, cysteic acid); reviewed in Hawkins et al. (91). Disulfides (e.g., cystine) can also be oxidized by $\mathrm{HOCl}$, with some of these reactions being very fast due to stabilization of the $S$-chlorinated intermediate

\section{B Lipids and antioxidants}

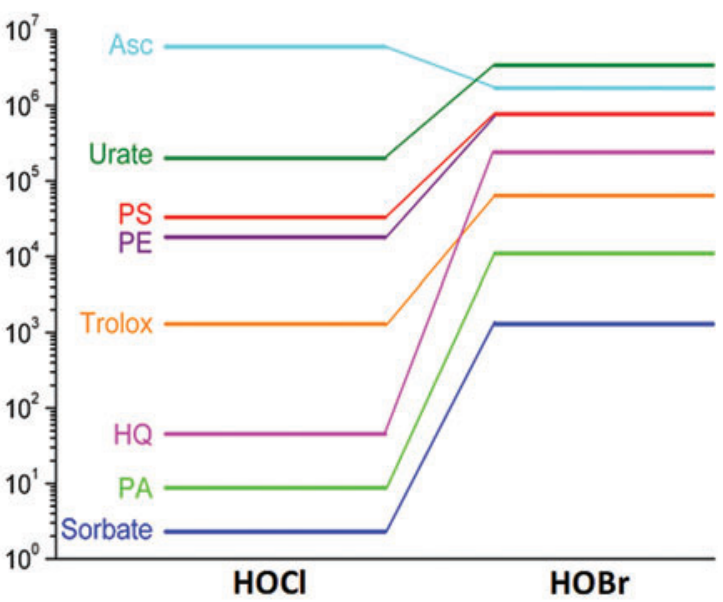

FIG. 3. Plots comparing the known second-order rate constants (on a log scale) for selected reactions of hypohalous acids with model biological substrates. (A) $\mathrm{HOCl}, \mathrm{HOBr}$, and $\mathrm{HOSCN}$ with model compounds of protein and (B) $\mathrm{HOCl}$ and $\mathrm{HOBr}$ with model lipid components and antioxidants [reviewed in Pattison and Davies (186)]. The majority of the rate constants were determined in phosphate-buffered solutions at $\mathrm{pH} 7.2-7.5$ and $22^{\circ} \mathrm{C}(184,228)$. HOBr, hypobromous acid; HOSCN, hypothiocyanous acid; HQ, hydroquinone; PA, pentenoic acid (double bond); PE, phosphoryl-ethanolamine; PS, phosphoryl-Ser. Color images are available online. 
Table 3. Summary of the Second-Order Rate Constants and Products for Reactions of HOCl and HOSCN with Biologically Relevant Thiols, Selenols, Thioethers and Selenides

\begin{tabular}{|c|c|c|c|c|}
\hline \multirow[b]{2}{*}{ Substrate } & \multicolumn{2}{|c|}{$\begin{array}{l}\text { Second-order rate } \\
\text { constants } k_{2} / \mathrm{M}^{-1} \cdot s^{-1}\end{array}$} & \multicolumn{2}{|c|}{ Products } \\
\hline & $\mathrm{HOCl}$ & HOSCN & $\mathrm{HOCl}$ & HOSCN \\
\hline Cysteine (Cys) & $3.6 \times 10^{8, a}$ & $7.8 \times 10^{4, b}$ & $\begin{array}{l}\text { Sulfenyl chloride (RS-Cl); } \\
\text { sulfenic acid (RS-OH); } \\
\text { sulfinic/sulfonic acids; } \\
\text { disulfides (RS-SR') }\end{array}$ & $\begin{array}{l}\text { Sulfenyl thiocyanate }(\mathrm{RS}-\mathrm{SCN}) \\
\text { sulfenic acid (RS-OH); sulfinic/ } \\
\text { sulfonic acids; disulfides (RS-SR') }\end{array}$ \\
\hline $\begin{array}{l}\text { Glutathione } \\
\text { (GSH) }\end{array}$ & $1.3 \times 10^{8, \mathrm{a}}$ & $2.5 \times 10^{4, b}$ & $\begin{array}{l}\text { GSSG; glutathione sulfonic } \\
\text { acid; glutathione sulfonamide; } \\
\text { mixed disulfides (GS-SR) }\end{array}$ & GSSG; mixed disulfides (GS-SR) \\
\hline $\begin{array}{l}\text { Methionine } \\
\text { (Met) }\end{array}$ & $3.4 \times 10^{7, a}$ & $<10^{3, \mathrm{~b}}$ & $\begin{array}{l}\text { Methionine sulfoxide (MetSO); } \\
\text { methionine sulfone }\left(\mathrm{MetSO}_{2}\right) \\
\text { dehydromethionine }\end{array}$ & No reaction \\
\hline $\begin{array}{l}\text { Selenocysteine } \\
\quad(\mathrm{Sec})^{\mathrm{c}}\end{array}$ & ND & $1.24 \times 10^{6, \mathrm{~d}}$ & $\begin{array}{l}\text { Selenyl chloride }(\mathrm{RSe}-\mathrm{Cl}) ; \\
\text { selenenic acid (RSe-O -/RSe-OH); } \\
\text { seleninic/selenonic acids; } \\
\text { diselenides (RSe-SeR'); } \\
\text { mixed RSe-SR' }\end{array}$ & $\begin{array}{l}\text { Selenyl thiocyanate }(\mathrm{RSe}-\mathrm{SCN}) \text {; } \\
\text { selenenic acid }(\mathrm{RSe}-\mathrm{O}-/ \mathrm{RSe}-\mathrm{OH}) ; \\
\text { seleninic/selenonic acids; diselenides } \\
\left(\mathrm{RSe}-\mathrm{SeR}^{\prime}\right) ; \text { mixed RSe-SR' }\end{array}$ \\
\hline $\begin{array}{l}\text { Selenomethionine } \\
\quad \text { (SeMet) }\end{array}$ & ND & $2.8 \times 10^{3, \mathrm{~d}}$ & Methionine selenoxide (MetSeO) & Methionine selenoxide (MetSeO) \\
\hline
\end{tabular}

by either remote lone pairs of electrons or by the neighboring sulfur atom when the orbitals are favorably oriented (117). These reactions yield thiosulfinates $\left[\mathrm{RS}(\mathrm{O}) \mathrm{SR}^{\prime}\right]$ and eventually $\mathrm{RSO}_{2} \mathrm{H}$ and $\mathrm{RSO}_{3} \mathrm{H}$ with cleavage of the disulfide bond (Carroll et al., unpublished; Karimi et al., unpublished). $\mathrm{HOCl}$ can also induce the formation of sulfenamide ( $\left.\mathrm{RSNR}^{\prime}\right)$, sulfinamide $\left[\mathrm{RS}(\mathrm{O}) \mathrm{NR}^{\prime}\right]$, and sulfonamides $\left[\mathrm{RS}(\mathrm{O})_{2} \mathrm{NR}^{\prime}\right]$ (86), via nucleophilic attack of Lys or Arg side-chains on RS$\mathrm{Cl}$ or sulfenic or $\mathrm{RSO}_{2} \mathrm{H}$ intermediates. Glutathione sulfonamide, formed from GSH, is a sensitive marker for MPOmediated reactions (86) due to the high rate constant for oxidation of GSH (238).

The high susceptibility of Cys residues to oxidation results in inactivation of enzymes (e.g., creatine kinase and glyceraldehyde-3-phosphate dehydrogenase, GAPDH) that have Cys residues, and particularly those with low $\mathrm{pK}_{\mathrm{a}}$ Cys residues in their active sites, with inactivation occurring in parallel with thiol depletion $(194,199)$. Conversely, $\mathrm{HOCl}$ can activate the proforms of matrix metalloproteinases (e.g., MMP-7) via oxidation of the Cys residue in the "cysteine switch" domain of pro-MMP-7 (68).

Oxidation of Met side-chains by $\mathrm{HOCl}$ yields the sulfoxide (and the sulfone with large excesses) $(90,189)$. These species are readily formed, but are poor markers for MPO damage as they are also produced by other oxidants. Met oxidation can result in enzyme inactivation in some cases (e.g., lysozyme and $\alpha_{1}$-antitrypsin), but not others (e.g., soybean trypsin inhibitor) (90).

Amines (and to a lesser extent amides and guanidines) are readily converted to $\mathrm{N}$-chlorinated species (chloramines, $\mathrm{RR}^{\prime} \mathrm{NCl}$ ). Further reaction with $\mathrm{HOCl}$ can result in the formation of dichloramines $\left(\mathrm{RNCl}_{2}\right)$, particularly with high excesses of oxidant (249). Chloramines are formed on reac- tion of free amino acids at the $\alpha$-amino group, and on the amine or guanidine groups of Lys, His, and Arg [reviewed in Hawkins et al. (91)]. In proteins, where the $\alpha$-amino group is part of an amide (peptide) bond, reaction is less rapid (183). Reaction can also occur with the indole nitrogen of Trp residues. With backbone amides and the amide side-chains of Gln and Asn, chloramides are formed with high $\mathrm{HOCl}$ excesses (183).

Amine groups on other biological molecules react similarly. The sulfonated $\beta$-amino acid, taurine, which is present in neutrophils and muscle cells at high concentrations, reacts rapidly with $\mathrm{HOCl}$ to give long-lived taurine chloramines [reviewed in Marcinkiewicz and Kontny (152)]. Chloramines are also formed rapidly at the amines present on nucleobases, nucleosides, nucleotides, RNA, and DNA (89), with reaction occurring at both the primary (exocylic) amines in cytosine, adenosine, and guanosine, and the secondary heterocyclic amines in thymidine, uridine, and guanosine (89). The amine head groups of amine-containing phospholipids (e.g., phosphatidylethanolamine and phosphatidylserine) also react to give chloramines, but these are not formed to a significant extent at the quaternary amine of phosphatidylcholine (269).

$\mathrm{HOCl}$ reacts rapidly with aminosugars (e.g., glucosamine) and more slowly with the corresponding amide or sulfonamide species (205). These reactions can occur with both low-molecular-mass species, and also sugars in large glycosaminoglycans (e.g., hyaluronan, heparin, chondroitin-, heparan-, dermatan-, and keratin-sulfates) (205), and these species when present on glycoproteins and proteoglycans [e.g., perlecan (118)].

Chloramines and chloramides retain the oxidizing capacity of the parent oxidant, and can induce further reactions although at slower rates $(248,249)$. Some of these reactions regenerate the parent amine (e.g., via halogen transfer or 
radical reactions), while others result in loss or modification of the amine and formation of carbonyl or nitrile functions $(88,90,140,192,249)$. A major pathway for primary amines is loss of $\mathrm{HCl}$ to give an imine and subsequent hydrolysis of this species to give ammonium ions and a carbonyl [reviewed in Hawkins et al. (91)]. Hydrolysis of the chloramines formed on the imidazole ring of His is a potential pathway for the formation of 2-oxo-His (91) and related carbonyl compounds from nucleobases. Chloramines and chloramides can also decompose thermally, and in the presence of one-electron reductants (e.g., $\mathrm{Fe}^{2+}, \mathrm{Cu}^{+}$, and $\mathrm{O}_{2}^{-\bullet}$ ) to give nitrogencentered (aminyl) radicals $\left(\mathrm{RNH}^{\circ}\right)$ and $\mathrm{Cl}^{-}$. Aminyl radicals can induce hydrogen atom abstraction from other bonds resulting in further oxidative damage (e.g., Hawkins and Davies $(87,88)]$.

As chloramines and chloramides react more slowly and selectively than $\mathrm{HOCl}$, these can induce damage at sites remote from their site of formation, and hence may be major mediators of damage $(192,193,248)$. These species can oxidize Cys and Met residues on peptides, including GSH $(192,193)$. The reduced reactivity of these species results in some differences in the pattern of damage, with little evidence for the formation of glutathione sulfonamide (86). Low $\mathrm{pK}_{\mathrm{a}}$ Cys residues on enzymes and protein are particularly susceptible to damage $(192,193)$, and this may play a role in the induction of cellular apoptosis $(193,248,271)$ and the inactivation of specific intracellular enzymes $(193,248)$.

$\mathrm{HOCl}$ can undergo addition reactions with aromatic compounds and double bonds, including the side-chains of Tyr and Trp, nucleobases, and unsaturated fatty acid sidechains [reviewed in Hawkins et al. (91) and Pattison and Davies (185)]. Reaction with the Tyr phenolic side-chain yields Cl-Tyr, and 3,5-dichloro-tyrosine (diCl-Tyr) at high molar excesses. These long-lived products are widely used as highly characteristic, and specific, biomarkers of $\mathrm{HOCl}-$ mediated reactions [reviewed in Winterbourn (290)]. These may be formed via intermediate chloramines, as well as via direct reactions (90). Tyr residues are also oxidized to the dimer species $o-o^{\prime}$ dityrosine (di-Tyr) in low yield, probably via radical reactions (90). The indole side-chain of Trp can be converted to the 2-oxindole, possibly by addition of $\mathrm{HOCl}$ across the $\mathrm{C} 2-\mathrm{C} 3$ bond and subsequent hydrolysis $(69,91)$. Neighboring groups can modulate these reactions with cyclized products detected in proteins, when the group neighboring the Trp residue is a Gly or Ala (69).

With nucleobases, stable products featuring carbon/halogen bonds can be formed in addition to (unstable) chloramines. These include 5-chlorocytosine, 5-chloro( $2^{\prime}$-deoxy $)$ cytidine, 5-chlorouracil, 8-chloroadenine, 8-chloro( 2 '-deoxy)adenosine, and 8-chloro( $2^{\prime}$-deoxy)guanosine [reviewed in Hawkins et al. (92)]. Some of these (e.g., 5-chlorouracil, 5-chlorocytidine, and 8-chloroguanosine) have been detected in biological samples, and have been used as biomarkers of $\mathrm{HOCl}(11,100,172,243)$. Hydroxylated and ring-opened nucleobase products can also be formed $(158,285)$.

Addition of $\mathrm{HOCl}$ across double bonds (e.g., in unsaturated fatty acids and cholesterol) gives chlorohydrins $[\mathrm{RCH}=$ $\left.\mathrm{CHR}^{\prime}+\mathrm{HOX} \rightarrow \mathrm{RCH}(\mathrm{X})-\mathrm{CH}(\mathrm{OH}) \mathrm{R}^{\prime}\right](10)$. These can undergo further reaction to yield epoxides. The formation of these species on phospholipids can modulate the structure of cell membranes and result in cell lysis $(269,270)$. Similar species are formed on lipoproteins (34). The rate constants for the generation of these species are, however, slow relative to other reactions of $\mathrm{HOCl}(186,229)$. In contrast, plasmalogen lipids, which contain a vinyl ether linkage, react rapidly with $\mathrm{HOCl}$ (229) and this can result in cleavage of the ether linkage to give an $\alpha$-halogenated aldehyde and a lysophospholipid (251). Elevated levels of chlorinated aldehydes have been detected in a number of biological samples (e.g., human atherosclerotic lesions, lipoproteins, and cardiac tissue) and used as markers of HOCl-mediated damage (251). These $\alpha$-halogenated aldehydes have significant biological effects, and may act as signaling molecules (251) and inhibitors of enzymatic reactions (156).

Rate constants have been determined for many of the reactions of $\mathrm{HOCl}$. Much of the data have been obtained at $\mathrm{pH}$ 7-7.4, although some data have been reported at higher and lower $\mathrm{pH}$ values. These data indicate that $\mathrm{HOCl}$, rather than its anion $\left({ }^{-} \mathrm{OCl}\right)$, is the more reactive species, and many reactions therefore occur more rapidly at lower $\mathrm{pH}$ values. Some reactions, however, show a complex $\mathrm{pH}$ dependence (e.g., the imidazole ring of His) due to the presence of multiple ionizable groups on both the oxidant and target (183). The available kinetic data allow a "pecking order" to be determined for $\mathrm{HOCl}$ with different targets, and comparison with other oxidants (e.g., $\mathrm{HOBr}$ or $\mathrm{HOSCN})(183,186)$. As proteins and GSH are the most abundant targets within cells (in terms of dry mass, and also concentration of reactive sites), these are likely to be the major targets of initial oxidation. It should, however, be noted that the extent of reaction at a particular site and its biological importance do not necessarily coincide, as cells can sustain significant damage to nonessential sites, whereas highly selective damage at a limited set of sites may be lethal.

There are much lower levels of many antioxidants and protective systems extracellularly (82), and this can result in different targets being important. Thus, the plasma concentration of GSH (low $\mu M$ ) is very different to that within most cells (typically $2-10 \mathrm{mM}$ ), and the number of Cys (and to a less extent Met) residues on extracellular proteins is low. However, even under these conditions, proteins still appear to be the major target (190), although the sites of damage may differ compared with that within cells, with disulfide bonds being more significant targets extracellularly (and also potentially in the endoplasmic reticulum) where they can be abundant, compared with the cell cytosol (117).

\section{Reactions of $\mathrm{HOBr}$ and $\mathrm{HOSCN}$}

$\mathrm{HOBr}$ is a potent oxidant and brominating agent, and has similar reactivity to $\mathrm{HOCl}$ except with unsaturated residues [reviewed in Hawkins and Rayner (93) and Rayner et al. (202)]. Under normal physiological conditions, the formation of $\mathrm{HOBr}$ by MPO accounts for only a small minor proportion of the $\mathrm{H}_{2} \mathrm{O}_{2}$ consumed $(165,263)$, and therefore, a detailed discussion of $\mathrm{HOBr}$ chemistry is not provided here; Figure 3 summarizes some of the key data. In contrast, $\mathrm{SCN}^{-}$is a favored substrate for MPO, resulting in the formation of this oxidant under normal physiological conditions $(165,263)$. $\mathrm{HOSCN}$ can also be formed by direct reaction of $\mathrm{SCN}^{-}$with $\mathrm{HOCl}$ and $\mathrm{HOBr}(12,168)$. The $\mathrm{pK}_{\mathrm{a}}$ of HOSCN has been reported as 5.3 or 4.85 (169), with the latter more likely to be correct, so at $\mathrm{pH} 7.4$ the major form is the (less reactive) conjugate base, $\mathrm{OSCN}^{-}$. Although the nature of the oxidizing 
species has been debated, with various groups proposing the formation of thiocyanogen $(\mathrm{SCN})_{2}$, trithiocyanate $(\mathrm{SCN})_{3}{ }^{-}$, cyanosulfurous acid $\left(\mathrm{HO}_{2} \mathrm{SCN}\right)$, cyanosulfuric acid $\left(\mathrm{HO}_{3} \mathrm{SCN}\right)$, and cyanide $\left(\mathrm{CN}^{-}\right)$, there is considerable evidence for the formation of HOSCN [reviewed in Barrett and Hawkins (16)]. Radical formation [SCN ${ }^{\bullet}, \mathrm{OSCN}^{-}$, and/or $(\mathrm{SCN})_{2}{ }^{-\bullet}$ ] via the peroxidase cycle has also been proposed (143), although this is likely to be disfavored thermodynamically [reviewed in Barrett and Hawkins (16)].

Kinetic and product studies indicate that HOSCN is much less reactive and hence more selective than $\mathrm{HOCl}$ and $\mathrm{HOBr}$, with thiols being the major targets for $\operatorname{HOSCN}(16,187,230)$. Kinetic data indicate that these reactions are $\sim 10^{4}$-fold slower than with $\mathrm{HOCl}$ (Table 3$)(230,238)$. The major initial products formed by HOSCN with thiols are believed to be RS-SCN species, with these reacting rapidly either with $\mathrm{H}_{2} \mathrm{O}$ to give $\mathrm{RSOH}$, or another thiol to give a disulfide $(16,17$, 144). This targeting can result in selective damage to thioldependent enzymes [and particularly those with low $\mathrm{pK}_{\mathrm{a}}$ thiols $(8,17,232)]$, and GSH within cells $(17,144)$. For example, the selective nature of this oxidant results in more efficient (by 10- to 1000-fold) inactivation of membrane ATPases than with identical concentrations of $\mathrm{HOCl}$ (8). Exposure of endothelial cells to HOSCN can induce tissue factor activity (276) and promote adhesion molecule expression (275), possibly via site-specific oxidation of redoxsensitive thiols and NF- $\kappa \mathrm{B}$ activation (178). If this is correct, multiple genes may be upregulated following cell exposure to HOSCN (275).

HOSCN also reacts rapidly with the selenol group (RSeH) of selenocysteine $(\mathrm{Sec})$, with these reactions being 10- to 100-fold faster than for the sulfur analog, Cys (Table 3) (231). This can result in inactivation of key Sec-dependent enzymes such as thioredoxin reductase (TrxR) and glutathione peroxidase (231). Limited evidence has also been presented for slow reaction with aromatic residues (Tyr, His, and Trp), but these reactions are unlikely to be of major significance within cells due to the abundance of GSH and protein thiols (23).

Decay of HOSCN yields a complex mixture of species, including significant levels of cyanate, $\mathrm{OCN}^{-}$(8). This species is also formed from the decomposition of urea (hence is of significance in subjects with uremia), and via reaction of $\mathrm{CN}^{-}$with MPO (54). Cyanate undergoes adduction reactions with Cys, and the side-chain amine group of Lys, to give a carbamylated product [homocitrulline, $\mathrm{RN}-\mathrm{C}(\mathrm{O}) \mathrm{NH}_{2}$ ], which has been suggested as a surrogate biomarker for HOSCN in vivo (280). Homocitrulline formation has been detected in uremia-induced damage, and on dysfunctional lipoproteins [reviewed in Sirpal (227)]. There is limited evidence for the reaction of $\mathrm{HOSCN}$ or $\mathrm{OCN}^{-}$with other targets, including amino sugars, phospholipid head groups, or nucleobases $(16,256)$, although $(\mathrm{SCN})_{2}$ may add across double bonds to give products analogous to chlorohydrins (81).

\section{Reactions of other MPO-derived oxidants}

$\mathrm{NO}_{2}{ }^{\bullet}$ is formed by the oxidation of nitrite, $\mathrm{NO}_{2}{ }^{-}$, by MPO in the presence of $\mathrm{H}_{2} \mathrm{O}_{2}(58,264) . \mathrm{NO}_{2}{ }^{\bullet}$ is a key intermediate in MPO-mediated nitration of Tyr residues, probably via MPO-mediated tyrosyl radical formation and radical/radical termination with $\mathrm{NO}_{2}{ }^{\bullet}$ (264). $\mathrm{NO}_{2}{ }^{\bullet}$ has been implicated in peroxidase-mediated peroxidation of low-density lipoproteins (LDL) in the presence of $\mathrm{NO}_{2}{ }^{-}$, both in vitro (29) and in inflammation models (309). Nitryl chloride $\left(\mathrm{NO}_{2} \mathrm{Cl}\right)$ has been postulated to be formed by activated leukocytes, possibly via indirect reaction of $\mathrm{HOCl}$ with $\mathrm{NO}_{2}^{-}$(57). This reaction is slow $\left[k \sim 10^{4} M^{-1} \cdot \mathrm{s}^{-1}(180)\right]$ compared with other $\mathrm{HOCl}$ reactions and may be of limited relevance in cells (287), although $\mathrm{NO}_{2} \mathrm{Cl}$ can nitrate and chlorinate phenols, including Tyr, (58), and DNA bases (43), as well as generating Tyr dimers (58) in vitro. A role for $\mathrm{NO}_{2} \mathrm{Cl}$ in lipid peroxidation has been discounted (29).

Singlet oxygen $\left({ }^{1} \Delta_{\mathrm{g}},{ }^{1} \mathrm{O}_{2}\right)$, the first excited singlet state of molecular $\mathrm{O}_{2}$, has been suggested to be formed by activated leukocytes, although the specificity of the probes used has been questioned [reviewed in Klebanoff (130)]. However, there is evidence that ${ }^{1} \mathrm{O}_{2}$ may arise from peroxidase reaction products, including via reaction of $\mathrm{HOCl}$ with $\mathrm{H}_{2} \mathrm{O}_{2}$ (115). ${ }^{1} \mathrm{O}_{2}$ formation by neutrophils undergoing phagocytosis, and activated macrophages, has also been reported using compounds that (specifically) trap ${ }^{1} \mathrm{O}_{2}(7)$. Reaction of $\mathrm{HOCl}$ with $\mathrm{H}_{2} \mathrm{O}_{2}$ is kinetically slow, compared with other reactions at physiological concentrations [reviewed in Tarr and Valenzeno (244)], and thus, it has been concluded that ${ }^{1} \mathrm{O}_{2}$ is unlikely to be formed in high yields in the neutrophil phagosome (291). HOCl can also react with lipid hydroperoxides to yield ${ }^{1} \mathrm{O}_{2}$ via peroxyl radical intermediates (162), although it has been suggested that this may not be important (179).

MPO can generate phenoxyl radicals from phenols in the presence of $\mathrm{H}_{2} \mathrm{O}_{2}$, in in vitro model systems, cells, and animal models (98). MPO can generate di-Tyr, via radical/radical termination of tyrosyl radicals, and free tyrosyl radicals have been reported to oxidize protein $\mathrm{Tyr}$ residues, thereby yielding di-Tyr crosslinks with proteins (99). Protein Tyr residues do not appear to be directly oxidized by MPO, presumably because of steric interactions (254). Tyrosyl radicals can react with ascorbate and unsaturated phospholipids, resulting in the oxidation of these species (98). MPOderived tyrosyl radicals are potential initiators of LDL lipid peroxidation in vitro (219), but the relevance of this process in vivo has been questioned (309). Other phenols and related species can also be converted to radicals [e.g., Kettle et al. (121, 123)]. Acetaminophen (paracetamol)-derived radicals can initiate LDL lipid peroxidation in the presence of MPO or neutrophils (116). Phenol itself is a good substrate for MPO, although the lipid oxidation observed in cells may be mediated by glutathionyl radicals $\left(\mathrm{GS}^{\bullet}\right)$ formed via hydrogenabstraction from GSH by initial phenoxyl radicals (24). Urate is also a good substrate for MPO (221), with this resulting in the formation of urate radicals that subsequently yield urate hydroperoxides (182). $\mathrm{HO}^{\bullet}$ may be generated indirectly via reaction of $\mathrm{O}_{2}^{-\bullet}$ with $\mathrm{HOCl}(31)$, however, the physiological relevance of this process is questionable, due to the modest levels of $\mathrm{O}_{2}^{-\bullet}$ in vivo and the reactivity of $\mathrm{HOCl}$ with other targets (291).

\section{Cellular systems}

The reactivity of $\mathrm{HOCl}$ with cells in vitro, including numerous types of mammalian cells (202), bacteria $(85,292)$, and yeast (33), has been studied extensively, and there is no doubt as to the damaging nature of this oxidant. $\mathrm{HOBr}$ and 
HOSCN also react with cells, although there are key differences in the cytotoxicity and selectivity when compared with $\mathrm{HOCl}(93,187)$. With HOSCN, these differences have led to the proposal that in vivo $\mathrm{SCN}^{-}$supplementation may have therapeutic value, by altering both the nature and extent of MPO-induced damage $(41,187)$.

Exposure of cells to $\mathrm{HOCl}$ results in cell death, in a cell type, time-, and dose-dependent manner, via a range of different pathways [reviewed in Rayner et al. (202)]. HOCl can induce direct cell lysis by reacting with the cell membrane, as demonstrated with red blood cells, with $\mathrm{HOCl}$-induced hemolysis attributed to the modification of membranes and cytoskeletal proteins rather than lipid oxidation (269). Leukocytes, including monocytes and macrophages, are also sensitive to HOCl-induced damage, with this characterized by mitochondrial dysfunction, release of proinflammatory signaling molecules, and necrotic cell death (142, 203, 297). With endothelial cells, $\mathrm{HOCl}$ treatment also leads to mitochondrial dysfunction and perturbation of signaling cascades, although in this case, there is evidence for both necrosis and apoptotic cell death $(141,273)$. HOCl-induced cytotoxicity with physiologically relevant oxidant doses has also been reported in lung and bronchial epithelial cells (77), chondrocytes (284), fibroblasts (102), and vascular smooth muscle cells (VSMC) (113).

The variation in the sensitivity of different cells, or between the same cell type from different donors, to $\mathrm{HOCl}$, has been attributed, at least in part, to differences in the concentration of GSH, which is rapidly depleted by this oxidant $(113,142,199,272,297)$. Cell exposure to $\mathrm{HOCl}$ also results in the rapid oxidation of thiol-containing proteins, which causes loss of enzymatic activity $(194,242)$. One example is GAPDH, an abundant, thiol-dependent enzyme, which is known to be targeted by $\mathrm{HOCl}$ and related oxidants in multiple cells [e.g., Lloyd et al. (141, 142), Pullar et al. (199), and Yang et al. (297)], with this leading to decreased glycolytic activity and reduced ATP production (144). Targeting of thiol proteins can perturb $\mathrm{Ca}^{2+}$ homeostasis by various pathways, including by modulation of the activity of sarco/ endoplasmic reticulum (SR) $\mathrm{Ca}^{2+}$ ATPase (SERCA) $(46,61)$, L-type $\mathrm{Ca}^{2+}$ channels $(83,296)$, and the ryanodine receptor (RyR) (296).

The extent of the $\mathrm{Ca}^{2+}$ perturbations arising from $\mathrm{HOCl}$ exposure can influence the extent of cell survival, which may be related to mitochondrial dysfunction and changes in mitochondrial membrane potential $\left(\Delta \Psi_{\mathrm{m}}\right)$ and permeability (288). Altered $\mathrm{Ca}^{2+}$ fluxes within the cells also influence signaling pathways involving tyrosine phosphorylation (220). Phosphorylation cascades can be dysregulated by the direct reaction of $\mathrm{HOCl}$ with phosphotyrosine phosphatases, as these contain a highly reactive thiol in their active site (108). This can enhance the extent of phosphorylation of mitogen-activated protein kinases (MAPK), including extracellular signal-regulated kinase (ERK 1/2) and p38, which play a critical role in controlling cellular differentiation, growth, and survival pathways (135, 161, 286).

The nuclear factor erythroid 2-related factor 2 (Nrf2)/ antioxidant response element (ARE) pathway is an important protective and adaptive response system that can be activated in cells by $\mathrm{HOCl}(195,282,293)$. This activation may replenish depleted intracellular GSH pools, as the expression of glutamate cysteine ligase catalytic subunit (GCLC), gluta- thione synthetase (GS), and glutathione reductase (GR) is regulated by Nrf2. Activation of Nrf2 also induces heme oxygenase 1 (HO-1) as well as enzymes involved in GSH metabolism, which have been reported to be upregulated in cells exposed to $\mathrm{HOCl}$, with a resultant decreased cytotoxicity $(195,282)$.

$\mathrm{HOCl}$ therefore appears to induce cell dysfunction and death via multiple pathways, involving rapid loss of intracellular GSH, an accumulation in cytosolic $\mathrm{Ca}^{2+}$, triggering of mitochondrial dysfunction by decreasing $\Delta \Psi_{\mathrm{m}}$, enzyme inactivation, and a loss of ATP stores. This culminates in activation of cellular stress responses and cell death. The specific mechanism of cell death following $\mathrm{HOCl}$ exposure in different cell types can also influenced by the oxidant concentration, with high $\mathrm{HOCl}$ concentrations being typically associated with necrosis, and low concentrations with apoptosis, particularly in endothelial cells $(141,199,240,271$, 273).

Apoptotic cell death induced by $\mathrm{HOCl}$ is characterized by increased binding of Annexin V, DNA fragmentation, and release of mitochondrial cytochrome $c$ and other proapoptotic proteins. This has been attributed to the mitochondrial translocation of proapoptotic Bax (284). HOCl-induced apoptosis can also occur by caspase-independent pathways, as evidenced by a lack of efficacy of the pan-caspase inhibitor Z-VAD-fmk in preventing cell death. This may be related to the capacity of $\mathrm{HOCl}$ to oxidize the active site Cys of caspases, thereby inhibiting their protease activity $(141,142$, 284).

\section{Targets of MPO Oxidants In Vivo and Disease}

Although there is compelling in vitro evidence that $\mathrm{HOCl}$ plays an important role in the induction of tissue damage and cell death (202), less is known regarding the mechanisms that may occur during MPO-mediated tissue damage in vivo. Typically, the involvement of MPO in pathologies has been inferred by the detection of elevated levels of the enzyme, or biomarkers of $\mathrm{HOCl}$ in the circulation, inflammatory fluids, urine, or diseased tissues (Table 1). These data, although important, do not readily allow the identification of the molecular targets or specific cellular pathways susceptible to MPO and its oxidants. In the sections below, we focus primarily on the role of MPO in cardiovascular, neurological, and respiratory diseases, where there is significant interest in therapeutic modulation of MPO activity. Data on other inflammatory pathologies are available in the references cited in Table 1.

\section{Vascular endothelium}

The vascular endothelium is a primary target for MPO, $\mathrm{HOCl}$, and biomolecules modified by $\mathrm{HOCl}$ such as LDL, high-density lipoprotein (HDL), or chlorinated lipids (150, $156,171,247)$. In atherosclerosis, which is characterized by endothelial dysfunction, there is significant evidence for elevated levels of enzymatically active MPO, and multiple markers of MPO-induced damage in diseased tissue [reviewed in Nicholls and Hazen (171) and Teng et al. (247)]. The observation that the extent of staining by an antibody raised against $\mathrm{HOCl}$-modified proteins correlates with disease severity [as assessed by intimal thickening in human lesions $(94,95)]$, together with the observation that MPO is 
present at particularly high levels in the rupture-prone, shoulder regions of lesions (49), strongly supports a role of $\mathrm{HOCl}$ in the development of atherosclerosis.

MPO-derived oxidants can readily induce endothelial dysfunction, as shown by the exposure of arterial rings $e x$ vivo to $\mathrm{HOCl}$ with this resulting in impaired endotheliumdependent relaxation $(237,303)$. This results from a reduction in the bioavailability of $\mathrm{NO}^{\circ}$, as a result of alterations in the expression, localization, activity, or substrate availability for endothelial nitric oxide synthase (eNOS) $(237,303)$. Similar observations have been reported in experiments with HOCl-modified LDL $(1,174)$. MPO can also induce endothelial dysfunction via $\mathrm{HOCl}$-independent pathways, including by directly reducing $\mathrm{NO}^{\bullet}$ bioavailability $(56,206)$, or mediating damage to extracellular matrix proteins following its transmigration through the endothelium (13). In addition, MPO can induce the collapse of the endothelial glycocalyx, which promotes the recruitment and activation of neutrophils (151). Taken together, these data corroborate and support clinical data showing that serum MPO levels can independently predict endothelial dysfunction in humans [e.g., Vita et al. (274)].

In addition to effects on $\mathrm{NO}^{\bullet}$ bioavailability, MPO can influence endothelial function by activating intracellular signaling cascades, which alter vascular function and promote inflammation. For example, MPO is believed to contribute to the development of pulmonary arterial hypertension by its ability to activate the Rho-kinase signaling pathway, which impairs vasorelaxation to increase right ventricular pressure (131). Similarly, activation of calpain by MPO increases inflammation by upregulating the expression of vascular cell adhesion molecules (VCAM), thereby promoting leukocyte adhesion to the endothelium (60). Calpain also plays a role in $\mathrm{NO}^{\bullet}$ regulation, which may be an additional pathway by which MPO can induce endothelial dysfunction (60).

The presence of MPO in the subendothelium has been implicated in plaque destabilization and thrombogenesis $(200,247)$ as $\mathrm{HOCl}$ promotes endothelial cell apoptosis (141, 273) and the release of tissue factor at sublethal oxidant doses (240). $\mathrm{HOCl}$ and $\mathrm{MPO}-\mathrm{H}_{2} \mathrm{O}_{2}-\mathrm{Cl}^{-}$directly damage extracellular matrix components such as fibronectin, laminins, perlecan, and basement membrane materials, both in vitro and in vivo, with this having adverse effects on associated endothelial and smooth muscle cell function, viability, and gene expression $(175,208)$. This direct oxidation may act in concert, or synergistically, with MPO-mediated activation of MMPs, as these species can destabilize plaques by their enzymatic activity (106). This may be further exacerbated by HOCl-mediated inactivation of the tissue inhibitors of metalloproteinases (TIMPs) (279). These in vitro studies support clinical observations on the colocalization of HOCl-modified proteins with macrophage MPO expression in lesions from patients who experienced sudden cardiac death (241), and help rationalize the prognostic value of MPO as a predictor of greater risk of myocardial infarction in patients with acute coronary syndrome $(14,26)$.

\section{Lipoproteins}

Modification of LDL and HDL by MPO and its oxidants can promote the proatherogenic properties of LDL, while compromising the cardioprotective effects of HDL, and thereby contribute to the development of atherosclerosis [reviewed in (150), Nicholls and Hazen (171), and Teng et al. (247)]. Evidence to support MPO-induced LDL modification comes from detection of increased levels of Cl-Tyr on LDL isolated from human lesions (97), with more recent data showing LDL-MPO complexes in the plasma of patients with atherosclerosis, particularly those with high levels of MPO in their circulation (233). In addition, HOCl-modified LDL is present in the plasma of patients undergoing hemodialysis (52).

HOCl-modified LDL can initiate a cascade of proinflammatory and atherogenic events (150). HOCl-modified LDL is recognized by macrophage scavenger receptors, including the class B scavenger receptors CD36 and SR-B1 (157), resulting in the accumulation of cholesterol and cholesteryl esters and foam cell formation (96). Exposure of macrophages to HOCl-LDL activates stress-related signaling responses, including Nrf2, to increase the expression of antioxidant genes (30) or promoting cell death by apoptosis (59). HOCl-modified LDL can also promote damage to endothelial cells by stimulating increased macrophage adhesion (134) and reducing the formation of $\mathrm{NO}^{\bullet}$ by eNOS delocalization (174) and uncoupling (1). Recent studies also provide evidence for a potential role for MPO-modified LDL in the resolution of inflammation in endothelial cells, via the induction of resolvin D1 (55).

Dysfunctional HDL extensively oxidized by MPO and $\mathrm{HOCl}$ is present in human atheroma and the circulation of patients with cardiovascular disease $(18,105,191,310)$. There is evidence indicating that MPO binds to apolipoprotein A1 (apoA1) in plasma, with this promoting HDL dysfunction (310). Modification of apoA1 both impairs the cholesterol acceptor function of $\operatorname{HDL}(18,310)$ and promotes proinflammatory activity of endothelial cells (105, 260). These effects are also apparent on infusion of apoA1 pretreated with MPO- $\mathrm{H}_{2} \mathrm{O}_{2}-\mathrm{Cl}^{-}$into atherosclerosis-prone mice (101). In this case, in contrast to observations with native apoA1, apoA1 oxidized by MPO failed to decrease macrophage number in the lesions or promote a noninflammatory macrophage phenotype (101). Finally, HOCl-induced modification of HDL inhibits the migration and proliferation of VSMC (311). This suggests that MPO-dependent HDL modifications can potentially promote inflammation, lesion development, and plaque instability in atherosclerosis.

\section{Brain and central nervous system}

MPO-induced endothelial dysfunction is also important in other pathologies, particularly neurological diseases, as it can contribute to the disruption and altered permeability of the blood/brain barrier (259). There is evidence for increased expression of MPO in the brains of patients with Alzheimer's disease (AD) (80, 212), Parkinson's disease (PD) (44), and multiple sclerosis (MS) (167). Recent studies demonstrate that the MPO expression is elevated in brain regions affected by neurodegeneration in both $\mathrm{AD}$ and PD (76). This supports previous data showing colocalization of MPO with $\beta$-amyloid peptide in senile plaques (212), and elevated levels of enzymatically active MPO and Cl-Tyr in the brain tissue of patients with AD (80). Similarly, Cl-Tyr and HOClmodified proteins are elevated in the brains of mice treated with 
the neurotoxin 1-methyl-4-phenyl-1,2,3,6-tetrahydropyridine (MPTP) to induce loss of dopaminergic neurons, as a model of PD (44).

The links between MPO and neurodegeneration in AD and PD are not well understood, but this may be related to the activation of microglia or astrocytes, which can produce MPO [e.g., Maki et al. (148)]. In AD, neurodegeneration and memory defects have been directly linked to the aberrant expression of MPO by astrocytes, and correlate with phospholipid oxidation, in humans and in vivo AD models (148). Whether phospholipid oxidation is causal in the disease, or merely indicative of an elevated oxidative stress as a result of increased MPO expression, is not clear. However, in vitro studies indicate that neuronal cells are highly susceptible to $\mathrm{HOCl}$, with exposure resulting in apoptotic or necrotic cell death, depending on the concentration and exposure conditions $(298,299)$. These cells also release proinflammatory cytokines, including $\mathrm{TNF} \alpha$ and IL- $1 \beta$ on $\mathrm{HOCl}$ exposure, thereby exacerbating neuroinflammation (137). In addition, $\mathrm{HOCl}$ may contribute indirectly to the development of PD by chlorinating the amine and catechol groups of dopamine to form chlorodopamines, which can selectively kill dopaminergic neurons by inhibiting mitochondrial respiration (112).

MPO has also been implicated in MS, a degenerative central nervous system disease characterized by the demyelination and transection of neuron axons, with this causing lesions (scleroses) throughout the brain and spinal cord (167). MPO has been detected in MS lesion macrophages and microglia (78), with $\mathrm{HOCl}$ production postulated to accelerate damage to the myelin sheath, neuronal damage, and ultimately neurodegeneration (67). Similar observations are reported in experimental autoimmune encephalomyelitis (EAE), a well-characterized in vivo model of MS [reviewed in Pravalika et al. (196) and Ray and Katyal (201)].

\section{Lungs/airway}

MPO and $\mathrm{HOCl}$ overproduction is strongly associated with several respiratory pathologies, including cystic fibrosis (CF) and chronic obstructive pulmonary disorder (Table 1). Peroxidase-mediated reactions are also important in asthma, although eosinophil peroxidase (EPO) and increased production of $\mathrm{HOBr}$ may be the dominating process in mediating lung injury (5). In CF, MPO activity in circulating neutrophils correlates with both airway obstruction and sputum production, consistent with MPO-derived oxidants contributing to airway injury (74). Moreover, it has been demonstrated that sputum and bronchoalveolar fluid from patients with $\mathrm{CF}$ contain active MPO and various markers of $\mathrm{HOCl}$-induced damage, including both chlorinated and brominated proteins (250).

GSH is depleted in the airways of children with $\mathrm{CF}$, and associated with increased levels of GSH sulfonamide, a specific oxidation product of $\mathrm{HOCl}$, and GSSG (oxidized glutathione) (124). These in vivo data are consistent with results from an ex vivo model of rabbit lung perfusion, where infusion of low concentrations of $\mathrm{HOCl}(1 \mu M)$ resulted in a marked depletion of GSH and other low-molecular-mass thiols (84). This oxidation was associated with increased vascular permeability, pulmonary artery pressure, and lung fluid retention (84). This corroborates in vivo studies demonstrating increased airway epithelial permeability on ex- posure to MPO-derived oxidants, and helps to rationalize the leakage of plasma proteins observed in the airway lumen of CF patients (209). As thiols are established targets of MPOderived oxidants, there is interest in the development of thiolbased therapeutics for use in $\mathrm{CF}(77,268)$.

MPO-derived oxidants are also indirectly implicated in exacerbating inflammation and lung damage in $\mathrm{CF}$, as $\mathrm{HOCl}$ targets the neutrophil-derived, protective protein calprotectin, in the airways of CF patients, which facilitates bacterial growth by compromising the chelation of essential metal ions (147). Similarly, $\mathrm{HOCl}$ can promote airway damage and remodeling by increasing protease activity, by inactivating protease inhibitors such as $\alpha_{1}$-antiproteinase, while activating latent collagenase and the metalloproteinase gelatinase (19). Finally, the systemic oxidative stress and endothelial dysfunction associated with increased MPO activity in patients with CF suggest that these individuals may also be at greater risk of developing cardiovascular pathologies [reviewed in Reverri et al. (211)].

\section{Modulation of MPO-Induced Damage}

The strong evidence for a role of MPO in inflammatory pathologies has led to significant interest in the development of inhibitors and approaches to modulate MPO activity in vivo as a therapeutic strategy. This has resulted in the development of several highly potent, irreversible inhibitors [reviewed in Lazarevic-Pasti et al. (136) and Soubhye et al. (234)]. Other approaches to modulate MPO-induced damage involve limiting substrate availability, promoting $\mathrm{H}_{2} \mathrm{O}_{2}$ removal, or supplementation with alterative MPO substrates [e.g., $\mathrm{SCN}^{-}$which has shown efficacy in in vivo $\mathrm{CF}$ models $(41,42)]$. We provide below a brief overview of these strategies; for further details, and information on specific diseases, the reader is referred to the referenced reviews.

\section{Limiting MPO substrate availability}

$\mathrm{As} \mathrm{Cl}^{-}$is highly abundant in vivo and therefore difficult to modulate, $\mathrm{H}_{2} \mathrm{O}_{2}$ availability is a key factor in determining the extent of MPO-derived oxidant formation. $\mathrm{H}_{2} \mathrm{O}_{2}$ is efficiently removed by enzymes, including peroxiredoxins, catalase, and glutathione peroxidases, in competition with MPO. $\mathrm{H}_{2} \mathrm{O}_{2}$ levels can also be limited by inhibition of the NADPH oxidase complexes that generate $\mathrm{O}_{2}^{-\bullet}$, and hence, $\mathrm{H}_{2} \mathrm{O}_{2}$ via dismutation (304). In the vasculature, it has been reported that $\mathrm{NO}^{\bullet}$ can suppress NADPH oxidase activity in endothelial cells by promoting the $S$-nitrosylation of the key $\mathrm{p} 47 \mathrm{phox}$ subunit of the enzyme, thereby limiting $\mathrm{H}_{2} \mathrm{O}_{2}$ levels (222).

MPO can also be diverted from $\mathrm{HOCl}$ production by supplementation with alternative substrates, such as $\mathrm{NO}_{2}{ }^{-}$or $\mathrm{SCN}^{-}(263,264)$. Oxidation of these anions yields alternative, potentially less damaging oxidants, and they can also react directly with $\mathrm{HOCl}$ (see Substrate specificity: halogenation cycle section). Supplementation with $\mathrm{NO}_{2}^{-}$has been proposed as a therapeutic strategy in neurodegenerative diseases, based on its ability to inhibit MPO-induced oxidative damage in neuronal cells in vitro (145). However, in other cell types, inhibition of MPO by $\mathrm{NO}_{2}^{-}$promoted neutrophil-induced DNA strand breakage (132). Addition of $\mathrm{SCN}^{-}$to cell cultures exposed to $\mathrm{MPO}-\mathrm{H}_{2} \mathrm{O}_{2}-\mathrm{Cl}^{-}$or $\mathrm{HOCl}$ in vitro reduces cellular damage and death $(41,294)$, although it is known that high (bolus) concentrations of 
HOSCN can be damaging and toxic [reviewed in Pattison et al. (187) and Rayner et al. (202)]. Supplementation with $\mathrm{SCN}^{-}$has been reported to be protective in inflammatory disease models in vivo [reviewed in Chandler and Day (41) and Day (51)], and high $\mathrm{SCN}^{-}$levels have been reported to have a marked anti-inflammatory effect and decrease bacterial loads in a murine $\mathrm{CF}$ model; these positive effects were associated with a restoration of GSH levels in the lungs (42). This may arise from upregulation of TrxR within the lung tissue, which can detoxify HOSCN, and hence preserve GSH (42). Similarly, supplementing atherosclerosis-prone mice, which overexpress human $\mathrm{MPO}$, with $\mathrm{SCN}^{-}$resulted in a marked decrease in plaque area (164). These protective effects have been detected at $\mathrm{SCN}^{-}$levels that can be readily achieved and tolerated in humans (164), but more work is needed to assess the mechanism(s) involved, and particularly whether this arises from an alteration in $\mathrm{HOCl}$ levels in these animals.

\section{Nonselective MPO inhibition}

MPO inhibition is an alternative approach, and a large number of compounds that prevent MPO-induced damage in a nonselective manner have been reported. Some of these lack specificity for MPO, including general heme poisons such as azide and $\mathrm{CN}^{-}$, and hence are unlikely to be of therapeutic relevance. Other inhibitors include various drugs, chelators, antioxidants, scavengers, and natural products, including various flavonoids/polyphenols. There are many compounds that can act as peroxidase substrates and divert the catalytic activity of MPO from its halogenation cycles. One approach is to use substrates that react readily with Compound I, but not Compound II, thereby resulting in a blocking of the enzymatic cycle, and less halide oxidation. This approach may have limited efficacy in vivo, as high concentrations would be required to compete with halide oxidation. Physiologically relevant concentrations of acetaminophen (paracetamol; $<130 \mu M$ ) inhibit oxidant production by $\mathrm{MPO}-\mathrm{H}_{2} \mathrm{O}_{2}-\mathrm{Cl}^{-}$ (133), although acetaminophen has also been reported to enhance $\mathrm{HOCl}$ production by recycling Compound II and Compound III (153). Similarly, a major dietary flavonoid, quercetin, can attenuate MPO-induced, endothelial dysfunction both in vitro and in vivo $(146,224)$, possibly by inhibiting MPO activity by acting as a cosubstrate (225). However, quercetin can also act by alternative pathways, such as by activation of Nrf2 and upregulation of HO-1 (224), attributed to quercetin oxidation products (47). Other in vitro studies have shown that the green tea polyphenol, epigallocatechin gallate (EGCG), can preserve endothelial function (252), with this reported to occur via binding of EGCG to the heme group of MPO and an accumulation of Compound II (252).

Cyclic nitroxides (e.g., TEMPO and derivatives) can also act as peroxidase substrates and react with Compound I to inhibit $\mathrm{HOCl}$ formation, as these species react slowly with Compound II $(114,204)$. This inhibition (as above) might be mitigated by reductants, such as $\mathrm{O}_{2}{ }^{\bullet-}$, that can recycle Compound II by reducing this to the ferric form (see above), but nitroxides can also act as SOD mimetics, suggesting efficacy as MPO inhibitors even in the presence of $\mathrm{O}_{2}{ }^{\bullet-}$ and/or absence of SOD. This is supported by studies showing nitroxide-dependent inhibition of $\mathrm{HOCl}$ production in an in vitro cardiomyocyte model of myocardial inflammation (39) and ex vivo in human plasma (114).
The peptide $N$-acetyl lysyltyrosylcysteine amide (KYC) is postulated to be a selective, reversible MPO inhibitor, which binds to the active site and reacts with Compounds I and II to form a tyrosyl radical that is efficiently scavenged by the adjacent Cys forming the KYC disulfide (305). This inhibitor has low toxicity, and is able to prevent $\mathrm{HOCl}$ formation and associated damage both in vitro (305) and in various in vivo disease models $(218,300,306,307)$. KYC reduced brain damage in murine models of stroke (300), and decreased the disease score in murine EAE models, which was associated with a decreased extent of protein oxidation and a restoration of the blood/brain barrier (306). Importantly, the protective effect of KYC was not seen in an analogous EAE model in MPO knockout mice, which supports the action of KYC being specific, and attributable to its MPO inhibitory capacity (306). KYC was also shown to improve vasodilatation in sickle cell disease mice (307) and inhibit tumor formation in a murine lung cancer model (218).

Other examples of nonselective MPO inhibitors include the copper-containing plasma protein ceruloplasmin, which binds strongly to MPO and inhibits its activity (233), and heparin, a polyanionic glycosaminoglycan widely used as anticoagulant, that binds (cationic) MPO electrostatically (48). The MPO binding capacity of heparin results in its release from blood vessels (15), a property that is reported to reflect plaque burden in patients with stable coronary artery disease (215).

Finally, a number of compounds have been identified that may modulate MPO-induced damage by acting as competitive targets for $\mathrm{HOCl}$. This strategy is only likely to be successful when high concentrations of these "scavengers" can be achieved. One potential species is taurine, which is present in high concentrations within neutrophils (152), with supplementation with taurine shown to decrease macrophage infiltration, elastin fragmentation, and MMP activation associated with the overexpression of MPO in an in vivo model of abdominal aortic aneurysms (128). Similarly, some seleniumcontaining compounds can react rapidly with MPO-derived oxidants (36), with the resulting selenoxides able to be catalytically recycled by cellular reductants and antioxidant enzymes (37). Although there are positive associations with selenium supplementation and beneficial disease outcomes, further studies are required to specifically assess whether this is related to a reduction in MPO-induced damage (35).

\section{Selective, irreversible MPO inhibitors}

"Suicide" substrates are likely to be the most specific and effective MPO inhibitors. The development and utilization of mechanism-based MPO inhibitors as therapeutic agents have been reviewed recently $(136,234)$. Briefly, hydrazines and hydrazides ( $\mathrm{RNHNH}_{2}$ and $\mathrm{RCONHNH}_{2}$, respectively) inhibit MPO via irreversible heme destruction (126). Thus, 4aminobenzoic acid hydrazide (ABAH) (122) induces heme loss via generation of ferrous MPO and subsequent reactions of this species (28). This compound has been used extensively in vitro, and to a lesser extent in vivo due to its toxicity, to examine the role of MPO in inducing cell dysfunction. However, ABAH supplementation can decrease inflammation and vascular oxidative stress in atherosclerosis-prone mice, improve endothelial function, and significantly reduce lesion development and neointima formation (255). ABAH 
has also shown to reduce infarct size and neuronal deficit in a murine model of stroke (66), and reduce disease severity in murine EAE, as a model of MS (67).

Thioxanthines are a class of compounds that have attracted significant clinical attention. These can covalently (and irreversibly) modify the heme groups of MPO and effectively inhibit $\mathrm{HOCl}$ production (253). These compounds have high potency and react rapidly with Compounds I and II of MPO, in a two-step mechanism (281). Studies in a murine model of peritoneal inflammation have shown that 2-thioxanthine is an effective inhibitor and decreases $\mathrm{HOCl}$ production in vivo (253). More recently, AZM198, a thioxanthine derivative developed by AstraZeneca, inhibits MPO activity in a tandem stenosis model of atherosclerotic plaque instability in apolipoprotein E knockout $\left(\mathrm{ApoE}^{-/-}\right)$mice (200). This results in an increase in the fibrous cap thickness in unstable plaques and highlights the potential utility of MPO inhibition as a clinical strategy to improve outcomes in high-risk coronary artery disease patients (200). AZM198 may also have therapeutic value in the prevention of MPO-induced adverse pulmonary vascular function, by mitigating the MPOdependent activation of Rho-kinase that is associated with increased pulmonary arterial hypertension (131).

\section{Conclusions and Future Perspectives}

There is now considerable evidence that strongly supports a role for MPO in the development of many inflammatory pathologies, which can result from effects mediated directly by MPO or from the excessive generation of MPO-derived oxidants, and particularly $\mathrm{HOCl}$. However, there are still significant gaps in our knowledge as to the mechanisms by which MPO appears extracellularly in inflamed tissues. Multiple pathways have been identified, including release from phagolysosomes, via the formation of neutrophil and other leukocyte extracellular traps ("NETosis" and related processes), or dysfunctional intracellular trafficking. Understanding these pathways is important as they may be amenable to therapeutic manipulation. Furthermore, there is still controversy as to precisely which cells (and phenotypes) release MPO. In particular, the role of tissue "macrophagelike" cells is disputed and is worthy of further study (159, $214,241)$. This is of particular relevance in the light of data from novel imaging modalities (such as bis-5HT-DTPA-Gd molecular magnetic resonance imaging [MPO-Gd MRI]) used to detect MPO in vivo, which have indicated that distinct macrophage subtypes may be important (214). Understanding the nature and role of different phenotypes, and subsequent manipulation of these, may provide routes to modulating tissue damage.

Further study also appears warranted with regard to the pattern and concentrations of oxidants formed by MPO under both physiological and pathological conditions, and how this is affected by the levels of different anions (halides or pseudohalide oxidized by the halogenation cycle) and oxidizable substrates (species that react with Compounds I and II in the peroxidase cycle). The role of MPO intermediates in consuming the critical biological signaling molecule $\mathrm{NO}^{\bullet}$, and generating nitrating species $\left(\mathrm{NO}_{2}{ }^{\bullet}\right.$ from $\left.\mathrm{NO}_{2}{ }^{-}\right)$, is also of considerable interest and relevance, particularly in the light of the many reports of the presence of nitrated biomolecules at sites of inflammation (63).
The growing body of evidence for a role for MPO in multiple human pathologies (Table 1) has also sparked considerable interest in the development and use of inhibitors of MPO. However, whether therapeutic interventions that inhibit oxidant production, or alter the nature of oxidants generated, can improve disease outcomes and survival in humans is yet to be firmly established. Promising results have been obtained in a number of in vivo disease models, including thioxanthines (AZM198) in cardiovascular disease, which influence the thickness of the fibrous cap and reduce intraplaque hemorrhage, which may be relevant for high-risk patient cohorts (200). Similarly, the tripeptide KYC has demonstrated efficacy reducing disease severity in animal models of stroke (300), EAE (306), sickle cell disease (307), and lung cancer (218).

However, the impact of long-term inhibitor use on immune function is of concern, and needs to be assessed. The thioxanthines have been shown to slow, but not prevent, the killing of Staphylococcus aureus by neutrophils (253); studies with other MPO inhibitors (such as the KYC peptide), and alternative bacterial strains or targets (e.g., yeasts), have not appeared in the literature. These data suggest that either residual MPO activity is sufficient for bactericidal activity or that other mechanisms can compensate for the inhibition of MPO. Thioxanthines inhibit thyroid peroxidase and lactoperoxidase to a much lesser extent than MPO as judged by in vitro assays [e.g., 10\% inhibition of thyroid peroxidase as concentrations that completely inhibit MPO (253)], and only marginally affected the formation of thyroid hormones in vivo (253), suggesting that "off-target" activity may not be a major limiting factor.

There may also be value in supplementation with anions, such as $\mathrm{SCN}^{-}$, which can act as alternative substrates for MPO, as the production of less potent, and slower reacting, oxidants such as HOSCN may reduce tissue damage while maintaining a capacity to control infection $(41,51)$. However, further work is clearly needed to assess the efficacy and consequences of such a strategy as this only reduces the extent of damage, with HOSCN (at least in vitro) being toxic to some cell types at high levels $(93,202)$.

\section{Funding Information}

The authors are grateful to the Novo Nordisk Foundation (grant: NNF13OC0004294 to M.J.D. and NNF17OC0028990 to C.L.H.) and the Danish Council for Independent Research (Det Frie Forskningsråd, grant: DFF-7014-00047 to M.J.D.) for financial support.

\section{References}

1. Abdo AI, Rayner BS, van Reyk DM, and Hawkins CL. Low-density lipoprotein modified by myeloperoxidase oxidants induces endothelial dysfunction. Redox Biol 13: 623-632, 2017.

2. Abu-Soud HM and Hazen SL. Nitric oxide is a physiological substrate for mammalian peroxidases. J Biol Chem 275: 37524-37532, 2000.

3. Albrett AM, Ashby LV, Dickerhof N, Kettle AJ, and Winterbourn CC. Heterogeneity of hypochlorous acid production in individual neutrophil phagosomes revealed by a rhodamine-based probe. J Biol Chem 293: 1571515724, 2018. 
4. Albrich JM, McCarthy CA, and Hurst JK. Biological reactivity of hypochlorous acid: implications for microbicidal mechanisms of leukocyte myeloperoxidase. Proc Natl Acad Sci U S A 78: 210-214, 1981.

5. Aldridge R, Chan T, van Dalen C, Senthilmohan R, Winn M, Venge P, Town G, and Kettle A. Eosinophil peroxidase produces hypobromous acid in the airways of stable asthmatics. Free Radic Biol Med 33: 847-856, 2002.

6. Alquoqa RS, Kasabri V, Naffa R, Akour A, and Bustanji Y. Cross-sectional correlates of myeloperoxidase and alpha-1-acid glycoprotein with adiposity, atherogenic and hematological indices in metabolic syndrome patients with or without diabetes. Ther Adv Endocrinol Metab 9: 283-291, 2018.

7. Arisawa F, Tatsuzawa H, Kambayashi Y, Kuwano H, Fujimori K, and Nakano M. MCLA-dependent chemiluminescence suggests that singlet oxygen plays a pivotal role in myeloperoxidase-catalysed bactericidal action in neutrophil phagosomes. Luminescence 18: 229-238, 2003.

8. Arlandson M, Decker T, Roongta VA, Bonilla L, Mayo $\mathrm{KH}$, MacPherson JC, Hazen SL, and Slungaard A. Eosinophil peroxidase oxidation of thiocyanatecharacterization of major reaction products and a potential sulfhydryl-targeted cytotoxicity system. J Biol Chem 276: 215-224, 2001.

9. Arnhold J, Monzani E, Furtmuller PG, Zederbauer M, Casella L, and Obinger C. Kinetics and thermodynamics of halide and nitrite oxidation by mammalian heme peroxidases. Eur J Inorg Chem 2006: 3801-3811, 2006.

10. Arnhold J, Panasenko OM, Schiller J, Vladimirov Yu A, and Arnold K. The action of hypochlorous acid on phosphatidylcholine liposomes in dependence on the content of double bonds. Stoichiometry and NMR analysis. Chem Phys Lipids 78: 55-64, 1995.

11. Asahi T, Kondo H, Masuda M, Nishino H, Aratani Y, Naito Y, Yoshikawa T, Hisaka S, Kato Y, and Osawa $\mathrm{T}$. Chemical and immunochemical detection of 8halogenated deoxyguanosines at early stage inflammation. J Biol Chem 285: 9282-9291, 2010.

12. Ashby MT, Carlson AC, and Scott MJ. Redox buffering of hypochlorous acid by thiocyanate in physiologic fluids. J Am Chem Soc 126: 15976-15977, 2004.

13. Baldus S, Eiserich JP, Mani A, Castro L, Figueroa M, Chumley P, Ma W, Tousson A, White CR, Bullard DC, Brennan ML, Lusis AJ, Moore KP, and Freeman BA. Endothelial transcytosis of myeloperoxidase confers specificity to vascular ECM proteins as targets of tyrosine nitration. J Clin Invest 108: 1759-1770, 2001.

14. Baldus S, Heeschen C, Meinertz T, Zeiher AM, Eiserich JP, Munzel T, Simoons ML, and Hamm CW. Myeloperoxidase serum levels predict risk in patients with acute coronary syndromes. Circulation 108: 1440-1445, 2003.

15. Baldus S, Rudolph V, Roiss M, Ito WD, Rudolph TK, Eiserich JP, Sydow K, Lau D, Szocs K, Klinke A, Kubala L, Berglund L, Schrepfer S, Deuse T, Haddad M, Risius T, Klemm H, Reichenspurner HC, Meinertz T, and Heitzer T. Heparins increase endothelial nitric oxide bioavailability by liberating vessel-immobilized myeloperoxidase. Circulation 113: 1871-1878, 2006.

16. Barrett TJ and Hawkins CL. Hypothiocyanous acid: benign or deadly? Chem Res Toxicol 25: 263-273, 2012.

17. Barrett TJ, Pattison DI, Leonard SE, Carroll KS, Davies MJ, and Hawkins CL. Inactivation of thiol-dependent enzymes by hypothiocyanous acid: role of sulfenyl thio- cyanate and sulfenic acid intermediates. Free Radic Biol Med 52: 1075-1085, 2012.

18. Bergt C, Fu X, Huq NP, Kao J, and Heinecke JW. Lysine residues direct the chlorination of tyrosines in YxxK motifs of apolipoprotein A-I when hypochlorous acid oxidizes HDL. J Biol Chem 279: 7856-7866, 2004.

19. Birrer P, McElvaney NG, Rudeberg A, Wirz Sommer C, Liechti-Gallati S, Kraemer R, Hubbard R, and Crystal RG. Protease-antiproteinase imbalance in the lungs of children with cystic fibrosis. Am J Respir Crit Care Med 150: 207213, 1994.

20. Blair-Johnson M, Fiedler T, and Fenna R. Human myeloperoxidase: structure of a cyanide complex and its interaction with bromide and thiocyanate substrates at 1.9 angstrom resolution. Biochemistry 40: 13990-13997, 2001.

21. Bolscher BG and Wever R. A kinetic study of the reaction between human myeloperoxidase, hydroperoxides and cyanide. Inhibition by chloride and thiocyanate. Biochim Biophys Acta 788: 1-10, 1984.

22. Bonaventura A, Liberale L, Carbone F, Vecchie A, DiazCanestro C, Camici GG, Montecucco F, and Dallegri F. The pathophysiological role of neutrophil extracellular traps in inflammatory diseases. Thromb Haemost 118: 627, 2018

23. Bonifay V, Barrett TJ, Pattison DI, Davies MJ, Hawkins CL, and Ashby MT. Tryptophan oxidation in proteins exposed to thiocyanate-derived oxidants. Arch Biochem Biophys 564: 1-11, 2014.

24. Borisenko GG, Martin I, Zhao Q, Amoscato AA, Tyurina YY, and Kagan VE. Glutathione propagates oxidative stress triggered by myeloperoxidase in HL-60 cellsevidence for glutathionyl radical-induced peroxidation of phospholipids and cytotoxicity. J Biol Chem 279: 2345323462, 2004.

25. Brennan M-L, Wu W, Fu X, Shen Z, Song W, Frost H, Vadseth C, Narine L, Lenkiewicz E, Borchers MT, Lusis AJ, Lee JJ, Lee NA, Abu-Soud HM, Ischiropoulos H, and Hazen SL. A tale of two controversies. Defining both the roleof peroxidases in nitrotyrosine formation in vivo using eosinophil peroxidase and myeloperoxidase-deficient mice, and the nature of peroxidase-generated reactive nirogen species. J Biol Chem 277: 17415-17427, 2002.

26. Brennan ML, Penn MS, Van Lente F, Nambi V, Shishehbor MH, Aviles RJ, Goormastic M, Pepoy ML, McErlean ES, Topol EJ, Nissen SE, and Hazen SL. Prognostic value of myeloperoxidase in patients with chest pain. $N$ Engl J Med 349: 1595-1604, 2003.

27. Brinkmann V and Zychlinsky A. Beneficial suicide: why neutrophils die to make NETs. Nat Rev Microbiol 5: 577582, 2007.

28. Burner U, Obinger C, Paumann M, Furtmuller PG, and Kettle AJ. Transient and steady-state kinetics of the oxidation of substituted benzoic acid hydrazides by myeloperoxidase. J Biol Chem 274: 9494-9502, 1999.

29. Byun J, Mueller DM, Fabjan JS, and Heinecke JW. Nitrogen dioxide radical generated by the myeloperoxidasehydrogen peroxide-nitrite system promotes lipid peroxidation of low density lipoprotein. FEBS Lett 455: 243-246, 1999.

30. Calay D, Rousseau A, Mattart L, Nuyens V, Delporte C, Van Antwerpen P, Moguilevsky N, Arnould T, Boudjeltia KZ, and Raes M. Copper and myeloperoxidase-modified LDLs activate Nrf2 through different pathways of ROS 
production in macrophages. Antioxid Redox Signal 13: 1491-1502, 2010.

31. Candeias LP, Patel KB, Stratford MRL, and Wardman $P$. Free hydroxyl radicals are formed on reaction between the neutrophil derived species superoxide anion and hypochlorous acid. FEBS Lett 333: 151-153, 1993.

32. Caramori G and Papi A. Oxidants and asthma. Thorax 59: 170-173, 2004.

33. Carmona-Gutierrez D, Alavian-Ghavanini A, Habernig L, Bauer MA, Hammer A, Rossmann C, Zimmermann AS, Ruckenstuhl C, Buttner S, Eisenberg T, Sattler W, Malle $\mathrm{E}$, and Madeo F. The cell death protease Kexlp is essential for hypochlorite-induced apoptosis in yeast. Cell Cycle 12: 1704-1712, 2013.

34. Carr AC, Decker EA, Park Y, and Frei B. Comparison of low-density lipoprotein modification by myeloperoxidasederived hypochlorous and hypobromous acids. Free Radic Biol Med 31: 62-72, 2001.

35. Carroll L, Davies MJ, and Pattison DI. Reaction of lowmolecular-mass organoselenium compounds (and their sulphur analogues) with inflammation-associated oxidants. Free Radic Res 49: 750-767, 2015.

36. Carroll L, Pattison DI, Fu S, Schiesser CH, Davies MJ, and Hawkins CL. Reactivity of selenium-containing compounds with myeloperoxidase-derived chlorinating oxidants: second-order rate constants and implications for biological damage. Free Radic Biol Med 84: 279-288, 2015.

37. Carroll L, Pattison DI, Fu S, Schiesser CH, Davies MJ, and Hawkins CL. Catalytic oxidant scavenging by selenium-containing compounds: reduction of selenoxides and N-chloramines by thiols and redox enzymes. Redox Biol 12: 872-882, 2017.

38. Casciaro M, Di Salvo E, Pace E, Ventura-Spagnolo E, Navarra M, and Gangemi S. Chlorinative stress in agerelated diseases: a literature review. Immun Ageing 14: 21, 2017.

39. Chami B, Jeong G, Varda A, Maw AM, Kim HB, Fong GM, Simone M, Rayner BS, Wang XS, Dennis JM, and Witting PK. The nitroxide 4-methoxy TEMPO inhibits neutrophil-stimulated kinase activation in $\mathrm{H} 9 \mathrm{c} 2$ cardiomyocytes. Arch Biochem Biophys 629: 19-35, 2017.

40. Chami B, Martin NJJ, Dennis JM, and Witting PK. Myeloperoxidase in the inflamed colon: a novel target for treating inflammatory bowel disease. Arch Biochem Biophys 645: 61-71, 2018.

41. Chandler JD and Day BJ. Biochemical mechanisms and therapeutic potential of pseudohalide thiocyanate in human health. Free Radic Res 49: 695-710, 2015.

42. Chandler JD, Min E, Huang J, McElroy CS, Dickerhof N, Mocatta T, Fletcher AA, Evans CM, Liang L, Patel M, Kettle AJ, Nichols DP, and Day BJ. Antiinflammatory and antimicrobial effects of thiocyanate in a cystic fibrosis mouse model. Am J Respir Cell Mol Biol 53: 193-205, 2015.

43. Chen HJ, Chen YM, Wang TF, Wang KS, and Shiea J. 8Nitroxanthine, an adduct derived from 2'-deoxyguanosine or DNA reaction with nitryl chloride. Chem Res Toxicol 14: 536-546, 2001.

44. Choi DC, Pennathur S, Perier C, Tieu K, Teismann P, Wu DC, Jackson-Lewis V, Vila M, Vonsattel JP, Heinecke JW, and Przedborski S. Ablation of the inflammatory enzyme myeloperoxidase mitigates features of Phh4arkinson's disease in mice. J Neurosci 25: 6594-6600, 2005.
45. Cojocaru IM, Cojocaru M, Iliescu I, Botnaru L, Gurban CV, Sfrijan F, and Tanasescu R. Plasma myeloperoxidase levels in patients with acute ischemic stroke. Rom J Intern Med 48: 101-104, 2010.

46. Cook NL, Viola HM, Sharov VS, Hool LC, Schoneich C, and Davies MJ. Myeloperoxidase-derived oxidants inhibit sarco/endoplasmic reticulum $\mathrm{Ca}^{2+}$-ATPase activity and perturb $\mathrm{Ca}^{2+}$ homeostasis in human coronary artery endothelial cells. Free Radic Biol Med 52: 951-961, 2012.

47. Croft KD, Zhang D, Jiang R, Ayer A, Shengule S, Payne RJ, Ward NC, and Stocker R. Structural requirements of flavonoids to induce heme oxygenase-1 expression. Free Radic Biol Med 113: 165-175, 2017.

48. Daphna EM, Michaela S, Eynat P, Irit A, and Rimon $\mathrm{S}$. Association of myeloperoxidase with heparin: oxidative inactivation of proteins on the surface of endothelial cells by the bound enzyme. Mol Cell Biochem 183: 55-61, 1998.

49. Daugherty A, Dunn JL, Rateri DL, and Heinecke JW. Myeloperoxidase, a catalyst for lipoprotein oxidation, is expressed in human atherosclerotic lesions. J Clin Invest 94: 437-444, 1994.

50. Davies MJ, Hawkins CL, Pattison DI, and Rees MD. Mammalian heme peroxidases: from molecular mechanisms to health implications. Antioxid Redox Signal 10: 1199-1234, 2008.

51. Day BJ. The science of licking your wounds: function of oxidants in the innate immune system. Biochem Pharmacol 163: 451-457, 2019.

52. Delporte C, Boudjeltia KZ, Noyon C, Furtmuller PG, Nuyens V, Slomianny MC, Madhoun P, Desmet JM, Raynal P, Dufour D, Koyani CN, Reye F, Rousseau A, Vanhaeverbeek M, Ducobu J, Michalski JC, Neve J, Vanhamme L, Obinger $\mathrm{C}$, Malle $\mathrm{E}$, and Van Antwerpen P. Impact of myeloperoxidase-LDL interactions on enzyme activity and subsequent posttranslational oxidative modifications of apoB-100. J Lipid Res 55: 747-757, 2014.

53. Delporte C, Van Antwerpen P, Vanhamme L, Roumeguere $\mathrm{T}$, and Zouaoui Boudjeltia K. Low-density lipoprotein modified by myeloperoxidase in inflammatory pathways and clinical studies. Mediators Inflamm 2013: 971579, 2013.

54. Delporte C, Zouaoui Boudjeltia K, Furtmuller PG, Maki RA, Dieu M, Noyon C, Soudi M, Dufour D, Coremans C, Nuyens V, Reye F, Rousseau A, Raes M, Moguilevsky N, Vanhaeverbeek M, Ducobu J, Neve J, Robaye B, Vanhamme L, Reynolds WF, Obinger C, and Van Antwerpen P. Myeloperoxidase-catalyzed oxidation of cyanide to cyanate: a potential carbamylation route involved in the formation of atherosclerotic plaques? J Biol Chem 293: 6374-6386, 2018.

55. Dufour D, Khalil A, Nuyens V, Rousseau A, Delporte C, Noyon C, Cortese M, Reye F, Pireaux V, Neve J, Vanhamme L, Robaye B, Lelubre C, Desmet JM, Raes M, Boudjeltia KZ, and Van Antwerpen P. Native and myeloperoxidase-oxidized low-density lipoproteins act in synergy to induce release of resolvin-D1 from endothelial cells. Atherosclerosis 272: 108-117, 2018.

56. Eiserich JP, Baldus S, Brennan ML, Ma W, Zhang C, Tousson A, Castro L, Lusis AJ, Nauseef WM, White CR, and Freeman BA. Myeloperoxidase, a leukocyte-derived vascular NO oxidase. Science 296: 2391-2394, 2002.

57. Eiserich JP, Cross CE, Jones AD, Halliwell B, and van der Vliet A. Formation of nitrating and chlorinating species by 
reaction of nitrite with hypochlorous acid. A novel mechanism for nitric oxide-mediated protein modification. J Biol Chem 271: 19199-19208, 1996.

58. Eiserich JP, Hristova M, Cross CE, Jones AD, Freeman BA, Halliwell B, and van der Vliet A. Formation of nitric oxide-derived inflammatory oxidants by myeloperoxidase in neutrophils. Nature 391: 393-397, 1998.

59. Ermak N, Lacour B, Goirand F, Drueke TB, and Vicca $\mathrm{S}$. Differential apoptotic pathways activated in response to $\mathrm{Cu}$-induced or $\mathrm{HOCl}$-induced LDL oxidation in U937 monocytic cell line. Biochem Biophys Res Commun 393: 783-787, 2010.

60. Etwebi Z, Landesberg G, Preston K, Eguchi S, and Scalia $\mathrm{R}$. Mechanistic role of the calcium-dependent protease calpain in the endothelial dysfunction induced by myeloperoxidase. Hypertension 71: 761-770, 2018.

61. Favero TG, Colter D, Hooper PF, and Abramson JJ. Hypochlorous acid inhibits $\mathrm{Ca}^{2+}$-ATPase from skeletal muscle sarcoplasmic reticulum. J Appl Physiol 84: 425430, 1998.

62. Fedeles BI, Freudenthal BD, Yau E, Singh V, Chang SC, Li D, Delaney JC, Wilson SH, and Essigmann JM. Intrinsic mutagenic properties of 5-chlorocytosine: a mechanistic connection between chronic inflammation and cancer. Proc Natl Acad Sci U S A 112: E4571-E4580, 2015.

63. Ferrer-Sueta G, Campolo N, Trujillo M, Bartesaghi S, Carballal S, Romero N, Alvarez B, and Radi $\mathrm{R}$. Biochemistry of peroxynitrite and protein tyrosine nitration. Chem Rev 118: 1338-1408, 2018.

64. Fiedler TJ, Davey CA, and Fenna RE. X-ray crystal structure and characterization of halide-binding sites of human myeloperoxidase at 1.8 angstrom resolution. $J$ Biol Chem 275: 11964-11971, 2000.

65. Folkes LK, Candeias LP, and Wardman P. Kinetics and mechanisms of hypochlorous acid reactions. Arch Biochem Biophys 323: 120-126, 1995.

66. Forghani R, Kim HJ, Wojtkiewicz GR, Bure L, Wu Y, Hayase M, Wei Y, Zheng Y, Moskowitz MA, and Chen JW. Myeloperoxidase propagates damage and is a potential therapeutic target for subacute stroke. J Cereb Blood Flow Metab 35: 485-493, 2015.

67. Forghani R, Wojtkiewicz GR, Zhang Y, Seeburg D, Bautz BR, Pulli B, Milewski AR, Atkinson WL, Iwamoto Y, Zhang ER, Etzrodt M, Rodriguez E, Robbins CS, Swirski FK, Weissleder R, and Chen JW. Demyelinating diseases: myeloperoxidase as an imaging biomarker and therapeutic target. Radiology 263: 451-460, 2012.

68. Fu X, Kassim SY, Parks WC, and Heinecke JW. Hypochlorous acid oxygenates the cysteine switch domain of pro- matrilysin (MMP-7). A mechanism for matrix metalloproteinase activation and atherosclerotic plaque rupture by myeloperoxidase. J Biol Chem 276: 41279-41287, 2001.

69. Fu X, Wang Y, Kao J, Irwin A, d'Avignon A, Mecham RP, Parks WC, and Heinecke JW. Specific sequence motifs direct the oxygenation and chlorination of tryptophan by myeloperoxidase. Biochemistry 45: 3961-3971, 2006.

70. Fuchs TA, Abed U, Goosmann C, Hurwitz R, Schulze I, Wahn V, Weinrauch Y, Brinkmann V, and Zychlinsky A. Novel cell death program leads to neutrophil extracellular traps. J Cell Biol 176: 231-241, 2007.

71. Furtmuller PG, Jantschko W, Zederbauer M, Schwanninger M, Jakopitsch C, Herold S, Koppenol WH, and
Obinger C. Peroxynitrite efficiently mediates the interconversion of redox intermediates of myeloperoxidase. Biochem Biophys Res Commun 337: 944-954, 2005.

72. Furtmuller PG, Zederbauer M, Jantschko W, Helm J, Bogner M, Jakopitsch C, and Obinger C. Active site structure and catalytic mechanisms of human peroxidases. Arch Biochem Biophys 445: 199-213, 2006.

73. Garcia AG, Rodriguez MR, Alonso CG, Ochoa DYR, and Aguilar CA. Myeloperoxidase is associated with insulin resistance and inflammation in overweight subjects with first-degree relatives with type 2 diabetes mellitus. Diabetes Metabol J 39: 59-65, 2015.

74. Garner HP, Phillips JR, Herron JG, Severson SJ, Milla $\mathrm{CE}$, and Regelmann WE. Peroxidase activity within circulating neutrophils correlates with pulmonary phenotype in cystic fibrosis. J Lab Clin Med 144: 127-133, 2004.

75. Garrity-Park M, Loftus EV, Jr., Sandborn WJ, and Smyrk TC. Myeloperoxidase immunohistochemistry as a measure of disease activity in ulcerative colitis: association with ulcerative colitis-colorectal cancer, tumor necrosis factor polymorphism and RUNX3 methylation. Inflamm Bowel Dis 18: 275-283, 2012.

76. Gellhaar S, Sunnemark D, Eriksson H, Olson L, and Galter D. Myeloperoxidase-immunoreactive cells are significantly increased in brain areas affected by neurodegeneration in Parkinson's and Alzheimer's disease. Cell Tissue Res 369: 445-454, 2017.

77. Gould NS, Gauthier S, Kariya CT, Min E, Huang J, and Day BJ. Hypertonic saline increases lung epithelial lining fluid glutathione and thiocyanate: two protective CFTRdependent thiols against oxidative injury. Respir Res 11: 119-128, 2010.

78. Gray E, Thomas TL, Betmouni S, Scolding N, and Love S. Elevated activity and microglial expression of myeloperoxidase in demyelinated cerebral cortex in multiple sclerosis. Brain Pathol 18: 86-95, 2008.

79. Gray E, Thomas TL, Betmouni S, Scolding N, and Love S. Elevated myeloperoxidase activity in white matter in multiple sclerosis. Neurosci Lett 444: 195-198, 2008.

80. Green PS, Mendez AJ, Jacob JS, Crowley JR, Growdon W, Hyman BT, and Heinecke JW. Neuronal expression of myeloperoxidase is increased in Alzheimer's disease. J Neurochem 90: 724-733, 2004.

81. Guy RG and Thompson JJ. Pseudohalogen chemistry VI. Homolytic thiocyanation of mono- and di-substituted alkenes using thiocyanogn and ultraviolet light. Tetrahedron 34: 541-546, 1978.

82. Halliwell B and Gutteridge JMC. The antioxidants of human extracellular fluids. Arch Biochem Biophys 280: 18, 1990.

83. Hammerschmidt $\mathrm{S}$ and Wahn $\mathrm{H}$. The effect of the oxidant hypochlorous acid on the L-type calcium current in isolated ventricular cardiomyocytes. J Mol Cell Cardiol 30: 1855-1867, 1998.

84. Hammerschmidt S and Wahn H. The oxidants hypochlorite and hydrogen peroxide induce distinct patterns of acute lung injury. Biochim Biophys Acta 1690: 258-264, 2004.

85. Hampton MB, Kettle AJ, and Winterbourn CC. Inside the neutrophil phagosome: oxidants, myeloperoxidase, and bacterial killing. Blood 92: 3007-3017, 1998.

86. Harwood DT, Kettle AJ, and Winterbourn CC. Production of glutathione sulfonamide and dehydroglutathione from GSH by myeloperoxidase-derived oxidants and detection 
using a novel LC-MS/MS method. Biochem J 399: 161168, 2006.

87. Hawkins CL and Davies MJ. Hypochlorite-induced damage to proteins: formation of nitrogen-centred radicals from lysine residues and their role in protein fragmentation. Biochem J 332: 617-625, 1998.

88. Hawkins CL and Davies MJ. Reaction of $\mathrm{HOCl}$ with amino acids and peptides: EPR evidence for rapid rearrangement and fragmentation reactions of nitrogencentered radicals. J Chem Soc, Perkin Trans 2: 19371945, 1998.

89. Hawkins CL and Davies MJ. Hypochlorite-induced damage to DNA, RNA and polynucleotides: formation of chloramines and nitrogen-centered radicals. Chem Res Toxicol 15: 83-92, 2002.

90. Hawkins CL and Davies MJ. Inactivation of protease inhibitors and lysozyme by hypochlorous acid: role of sidechain oxidation and protein unfolding in loss of biological function. Chem Res Toxicol 18: 1600-1610, 2005.

91. Hawkins CL, Pattison DI, and Davies MJ. Hypochloriteinduced oxidation of amino acids, peptides and proteins. Amino Acids 25: 259-274, 2003.

92. Hawkins CL, Pattison DI, Whiteman M, and Davies MJ. Chlorination and nitration of DNA and nucleic acid components. In: Oxidative Damage to DNA, edited by Evans MD and Cooke MS. Austin, TX: Landes Bioscience and Springer Science, 2006, pp. 14-39.

93. Hawkins CL and Rayner BS. Peroxidase-derived oxidants hypobromous acid and hypothiocyanous acid. In: Hydrogen Peroxide Metabolism in Health and Disease, edited by Vissers MCM, Hampton MB, and Kettle AJ. Boca Raton, FL: CRC Press, 2018, 327-350.

94. Hazell LJ, Arnold L, Flowers D, Waeg G, Malle E, and Stocker R. Presence of hypochlorite-modified proteins in human atherosclerotic lesions. J Clin Invest 97: 15351544, 1996.

95. Hazell LJ, Baernthaler G, and Stocker R. Correlation between intima-to-media ratio, apolipoprotein B-100, myeloperoxidase, and hypochlorite-oxidized proteins in human atherosclerosis. Free Radic Biol Med 31: 1254 1262, 2001.

96. Hazell LJ and Stocker R. Oxidation of low-density lipoprotein with hypochlorite causes transformation of the lipoprotein into a high-uptake form for macrophages. Biochem J 290: 165-172, 1993.

97. Hazen SL and Heinecke JW. 3-Chlorotyrosine, a specific marker of myeloperoxidase-catalysed oxidation, is markedly elevated in low density lipoprotein isolated from human atherosclerotic intima. J Clin Invest 99: 20752081, 1997.

98. Heinecke JW. Pathways for oxidation of low density lipoprotein by myeloperoxidase: tyrosyl radical, reactive aldehydes, hypochlorous acid and molecular chlorine. Biofactors 6: 145-155, 1997.

99. Heinecke JW, Li W, Francis GA, and Goldstein JA. Tyrosyl radical generated by myeloperoxidase catalyzes the oxidative cross-linking of proteins. J Clin Invest 91: 2866-2872, 1993.

100. Henderson JP, Byun J, Takeshita J, and Heinecke JW. Phagocytes produce 5-chlorouracil and 5-bromouracil, two mutagenic products of myeloperoxidase, in human inflammatory tissue. J Biol Chem 278: 23522-23528, 2003.

101. Hewing B, Parathath S, Barrett T, Chung WK, Astudillo YM, Hamada T, Ramkhelawon B, Tallant TC, Yusufishaq
MS, Didonato JA, Huang Y, Buffa J, Berisha SZ, Smith JD, Hazen SL, and Fisher EA. Effects of native and myeloperoxidase-modified apolipoprotein a-I on reverse cholesterol transport and atherosclerosis in mice. Arterioscler Thromb Vasc Biol 34: 779-789, 2014.

102. Hidalgo E, Bartolome R, and Dominguez C. Cytotoxicity mechanisms of sodium hypochlorite in cultured human dermal fibroblasts and its bactericidal effectiveness. Chem Biol Interact 139: 265-282, 2002.

103. Hori H, Fenna RE, Kimura S, and Ikeda-Saito M. Aromatic substrate molecules bind at the distal heme pocket of myeloperoxidase. J Biol Chem 269: 8388-8392, 1994.

104. Hoy A, Leininger-Muller B, Kutter D, Siest G, and Visvikis $\mathrm{S}$. Growing significance of myeloperoxidase in noninfectious diseases. Clin Chem Lab Med 40: 2-8, 2002.

105. Huang Y, DiDonato JA, Levison BS, Schmitt D, Li L, Wu Y, Buffa J, Kim T, Gerstenecker GS, Gu X, Kadiyala CS, Wang Z, Culley MK, Hazen JE, Didonato AJ, Fu X, Berisha SZ, Peng D, Nguyen TT, Liang S, Chuang CC, Cho L, Plow EF, Fox PL, Gogonea V, Tang WH, Parks JS, Fisher EA, Smith JD, and Hazen SL. An abundant dysfunctional apolipoprotein A1 in human atheroma. Nat Med 20: 193-203, 2014.

106. Hurst JK and Barrette WC, Jr. Leukocytic oxygen activation and microbicidal oxidative toxins. Crit Rev Biochem Mol Biol 24: 271-328, 1989.

107. Ikeda-Saito M. A study of ligand binding to spleen myeloperoxidase. Biochemistry 26: 4344-4349, 1987.

108. Janssen-Heininger YMW, Mossman BT, Heintz NH, Forman HJ, Kalyanaraman B, Finkel T, Stamler JS, Rhee SG, and van der Vliet A. Redox regulation of signal transduction: principles, pitfalls and promises. Free Radic Biol Med 45: 1-17, 2008.

109. Jantschko W, Furtmuller PG, Allegra M, Livrea MA, Jakopitsch C, Regelsberger G, and Obinger C. Redox intermediates of plant and mammalian peroxidases: a comparative transient-kinetic study of their reactivity toward indole derivatives. Arch Biochem Biophys 398: 1222, 2002.

110. Jantschko W, Furtmuller PG, Zederbauer M, Jakopitsch C, and Obinger $\mathrm{C}$. Kinetics of oxygen binding to ferrous myeloperoxidase. Arch Biochem Biophys 426: 91-97, 2004.

111. Jatakanon A, Uasuf C, Maziak W, Lim S, Chung KF, and Barnes PJ. Neutrophilic inflammation in severe persistent asthma. Am J Respir Crit Care Med 160: 1532-1539, 1999.

112. Jeitner TM, Kalogiannis M, Krasnikov BF, Gomolin I, Peltier MR, and Moran GR. Linking inflammation and Parkinson disease: hypochlorous acid generates Parkinsonian poisons. Toxicol Sci 153: 410, 2016.

113. Jenner AM, Ruiz JE, Dunster C, Halliwell B, Mann GE, and Siow RCM. Vitamin $\mathrm{C}$ protects against hypochlorous acid-induced glutathione depletion and DNA base and protein damage in human vascular smooth muscle cells. Arterioscler Thromb Vasc Biol 22: 574-580, 2002.

114. Kajer TB, Fairfull-Smith KE, Yamasaki T, Yamada K, Fu S, Bottle SE, Hawkins CL, and Davies MJ. Inhibition of myeloperoxidase- and neutrophil-mediated oxidant production by tetraethyl- and tetramethyl-nitroxides. Free Radic Biol Med 70: 96-105, 2014.

115. Kanofsky JR, Wright J, Milesrichardon GE, and Tauber AI. Biochemical requirements for singlet oxygen production by purified human myeloperoxidase. J Clin Invest 74: 1489-1495, 1984. 
116. Kapiotis S, Sengoelge G, Hermann M, Held I, Seelos C, and Gmeiner BM. Paracetamol catalyzes myeloperoxidaseinitiated lipid oxidation in LDL. Arterioscler Thromb Vasc Biol 17: 2855-2860, 1997.

117. Karimi M, Ignasiak MT, Chan B, Croft AK, Radom L, Schiesser CH, Pattison DI, and Davies MJ. Reactivity of disulfide bonds is markedly affected by structure and environment: implications for protein modification and stability. Sci Rep 6: 38572, 2016.

118. Kennett EC, Rees MD, Malle E, Hammer A, Whitelock JM, and Davies MJ. Peroxynitrite modifies the structure and function of the extracellular matrix proteoglycan perlecan by reaction with both the protein core and the heparan sulfate chains. Free Radic Biol Med 49: 282-293, 2010.

119. Kettle AJ, Anderson RF, Hampton MB, and Winterbourn CC. Reactions of superoxide with myeloperoxidase. Biochemistry 46: 4888-4897, 2007.

120. Kettle AJ, Chan T, Osberg I, Senthilmohan R, Chapman AL, Mocatta TJ, and Wagener JS. Myeloperoxidase and protein oxidation in the airways of young children with cystic fibrosis. Am J Respir Crit Care Med 170: 1317 1323, 2004.

121. Kettle AJ, Gedye CA, and Winterbourn CC. Superoxide is an antagonist of antiinflammatory drugs that inhibit hypochlorous acid production by myeloperoxidase. Biochem Pharmacol 45: 2003-2010, 1993.

122. Kettle AJ, Geyde CA, and Winterbourn CC. Mechanism of inactivation of myeloperoxidase by 4-aminobenzoic hydrazide. Biochem J 321: 503-508, 1997.

123. Kettle AJ, Robertson IGC, Palmer BD, Anderson RF, Patel KB, and Winterbourn CC. Oxidative metabolism of amsacrine by the neutrophil enzyme Myeloperoxidase. Biochem Pharmacol 44: 1731-1738, 1992.

124. Kettle AJ, Turner R, Gangell CL, Harwood DT, Khalilova IS, Chapman AL, Winterbourn CC, and Sly PD. Oxidation contributes to low glutathione in the airways of children with cystic fibrosis. Eur Respir J 44: 122-129, 2014.

125. Kettle AJ and Winterbourn CC. Oxidation of hydroquinone by myeloperoxidase-mechanism of stimulation by benzoquinone. J Biol Chem 267: 8319-8324, 1992.

126. Kettle AJ and Winterbourn CC. Myeloperoxidase: a key regulator of neutrophil oxidant production. Redox Rep 3: 3-15, 1997.

127. Kettle AJ and Winterbourn CC. A kinetic analysis of the catalase activity of myeloperoxidase. Biochemistry 40: 10204-10212, 2001.

128. Kim HW, Blomkalns AL, Ogbi M, Thomas M, Gavrila D, Neltner BS, Cassis LA, Thompson RW, Weiss RM, Lindower PD, Blanco VM, McCormick ML, Daugherty A, Fu X, Hazen SL, Stansfield BK, Huo Y, Fulton DJ, Chatterjee $\mathrm{T}$, and Weintraub NL. Role of myeloperoxidase in abdominal aortic aneurysm formation: mitigation by taurine. Am J Physiol Heart Circ Physiol 313: H1168-H1179, 2017.

129. Kisic B, Miric D, Dragojevic I, Rasic J, and Popovic L. Role of myeloperoxidase in patients with chronic kidney disease. Oxid Med Cell Longev 2016: 1069743, 2016.

130. Klebanoff SJ. Myeloperoxidase: friend and foe. J Leukoc Biol 77: 598-625, 2005.

131. Klinke A, Berghausen E, Friedrichs K, Molz S, Lau D, Remane L, Berlin M, Kaltwasser C, Adam M, Mehrkens D, Mollenhauer M, Manchanda K, Ravekes T, Heresi GA, Aytekin M, Dweik RA, Hennigs JK, Kubala L, Michaels- son E, Rosenkranz S, Rudolph TK, Hazen SL, Klose H, Schermuly RT, Rudolph V, and Baldus S. Myeloperoxidase aggravates pulmonary arterial hypertension by activation of vascular Rho-kinase. JCI Insight 3: e97530, 2018.

132. Knaapen AM, Schins RP, Borm PJ, and van Schooten FJ. Nitrite enhances neutrophil-induced DNA strand breakage in pulmonary epithelial cells by inhibition of myeloperoxidase. Carcinogenesis 26: 1642-1648, 2005.

133. Koelsch M, Mallak R, Graham GG, Kajer T, Milligan MK, Nguyen LQ, Newsham DW, Keh JS, Kettle AJ, Scott KF, Ziegler JB, Pattison DI, Fu S, Hawkins CL, Rees MD, and Davies MJ. Acetaminophen (paracetamol) inhibits myeloperoxidase-catalyzed oxidant production and biological damage at therapeutically achievable concentrations. Biochem Pharmacol 79: 1156-1164, 2010.

134. Kopprasch S, Pietzsch J, Westendorf T, Kruse HJ, and Grassler J. The pivotal role of scavenger receptor CD36 and phagocyte-derived oxidants in oxidized low density lipoprotein-induced adhesion to endothelial cells. Int $J$ Biochem Cell Biol 36: 460-471, 2004.

135. Lane AE, Tan JT, Hawkins CL, Heather AK, and Davies MJ. The myeloperoxidase-derived oxidant HOSCN inhibits protein tyrosine phosphatases and modulates cell signalling via the mitogen-activated protein kinase (MAPK) pathway in macrophages. Biochem J 430: 161169, 2010.

136. Lazarevic-Pasti T, Leskovac A, and Vasic V. Myeloperoxidase inhibitors as potential drugs. Curr Drug Metab 16: 168-190, 2015.

137. Lefkowitz DL and Lefkowitz SS. Microglia and myeloperoxidase: a deadly partnership in neurodegenerative disease. Free Radic Biol Med 45: 726-731, 2008.

138. Lehners A, Lange S, Niemann G, Rosendahl A, MeyerSchwesinger C, Oh J, Stahl R, Ehmke H, Benndorf R, Klinke A, Baldus S, and Wenzel UO. Myeloperoxidase deficiency ameliorates progression of chronic kidney disease in mice. Am J Physiol Renal Physiol 307: F407F417, 2014.

139. Li SB, Yang F, Jing L, Ma J, Jia YD, Dong SY, Zheng WF, and Zhao LS. Myeloperoxidase and risk of recurrence of atrial fibrillation after catheter ablation. J Investig Med 61: 722-727, 2013.

140. Lin H, Levison BS, Buffa JA, Huang Y, Fu X, Wang Z, Gogonea V, DiDonato JA, and Hazen SL. Myeloperoxidase-mediated protein lysine oxidation generates 2-aminoadipic acid and lysine nitrile in vivo. Free Radic Biol Med 104: 20-31, 2017.

141. Lloyd MM, Grima MA, Rayner BS, Hadfield KA, Davies MJ, and Hawkins CL. Comparative reactivity of the myeloperoxidase-derived oxidants hypochlorous acid and hypothiocyanous acid with human coronary artery endothelial cells. Free Radic Biol Med 65: 1352-1362, 2013.

142. Lloyd MM, Van Reyk DM, Davies MJ, and Hawkins CL. HOSCN is a more potent inducer of apoptosis and protein thiol depletion in murine macrophage cells than $\mathrm{HOCl}$ or HOBr. Biochem J 414: 271-280, 2008.

143. Lovaas E. Free radical generation and coupled thiol oxidation by lactoperoxidase/ $/ \mathrm{SCN}^{-} / \mathrm{H}_{2} \mathrm{O}_{2}$. Free Radic Biol Med 13: 187-195, 1992.

144. Love DT, Barrett TJ, White MY, Cordwell SJ, Davies MJ, and Hawkins CL. Cellular targets of the myeloperoxidasederived oxidant hypothiocyanous acid ( $\mathrm{HOSCN})$ and its role in the inhibition of glycolysis in macrophages. Free Radic Biol Med 94: 88-98, 2016. 
145. Lu N, Ding $Y$, Tian $R$, and Peng YY. Inhibition of myeloperoxidase-mediated oxidative damage by nitrite in SH-SY5Y cells: relevance to neuroprotection in neurodegenerative diseases. Eur J Pharmacol 780: 142-147, 2016.

146. Lu N, Sui Y, Tian R, and Peng YY. Inhibitive effects of quercetin on myeloperoxidase-dependent hypochlorous acid formation and vascular endothelial injury. J Agric Food Chem 66: 4933-4940, 2018.

147. Magon NJ, Turner R, Gearry RB, Hampton MB, Sly PD, and Kettle AJ. Oxidation of calprotectin by hypochlorous acid prevents chelation of essential metal ions and allows bacterial growth: relevance to infections in cystic fibrosis. Free Radic Biol Med 86: 133-144, 2015.

148. Maki RA, Tyurin VA, Lyon RC, Hamilton RL, DeKosky ST, Kagan VE, and Reynolds WF. Aberrant expression of myeloperoxidase in astrocytes promotes phospholipid oxidation and memory deficits in a mouse model of Alzheimer disease. J Biol Chem 284: 3158-3169, 2009.

149. Malle E, Buch T, and Grone HJ. Myeloperoxidase in kidney disease. Kidney Int 64: 1956-1967, 2003.

150. Malle E, Marsche G, Arnhold J, and Davies MJ. Modification of low-density lipoprotein by myeloperoxidasederived oxidants and reagent hypochlorous acid. Biochim Biophys Acta 1761: 392-415, 2006.

151. Manchanda K, Kolarova H, Kerkenpass C, Mollenhauer M, Vitecek J, Rudolph V, Kubala L, Baldus S, Adam M, and Klinke A. Myeloperoxidase reduces endothelial glycocalyx thickness dependent on its cationic charge. Arterioscler Thromb Vasc Biol 38: 1859-1867, 2018.

152. Marcinkiewicz J and Kontny E. Taurine and inflammatory diseases. Amino Acids 46: 7-20, 2014.

153. Marquez LA and Dunford HB. Interaction of acetaminophen with myeloperoxidase intermediates: optimum stimulation of enzyme activity. Arch Biochem Biophys 305: 414-420, 1993.

154. Marquez LA and Dunford HB. Chlorination of taurine by myeloperoxidase. Kinetic evidence for an enzyme-bound intermediate. J Biol Chem 269: 7950-7956, 1994.

155. Marquez LA and Dunford HB. Kinetics of oxidation of tyrosine and dityrosine by myeloperoxidase compounds I and II. Implications for lipoprotein peroxidation studies. J Biol Chem 270: 30434-30440, 1995.

156. Marsche G, Heller R, Fauler G, Kovacevic A, Nuszkowski A, Graier W, Sattler W, and Malle E. 2Chlorohexadecanal derived from hypochlorite-modified high-density lipoprotein-associated plasmalogen is a natural inhibitor of endothelial nitric oxide biosynthesis. Arterioscler Thromb Vasc Biol 24: 2302-2306, 2004.

157. Marsche G, Zimmermann R, Horiuchi S, Tandon NN, Sattler W, and Malle E. Class B scavenger receptors CD36 and SR-BI are receptors for hypochlorite-modified low density lipoprotein. J Biol Chem 278: 47562-47570, 2003.

158. Masuda M, Suzuki T, Friesen MD, Ravanat JL, Cadet J, Pignatelli B, Nishino H, and Ohshima H. Chlorination of guanosine and other nucleosides by hypochlorous acid and myeloperoxidase of activated human neutrophils. Catalysis by nicotine and trimethylamine. J Biol Chem 276: 40486-40496, 2001.

159. McMillen TS, Heinecke JW, and LeBoeuf RC. Expression of human myeloperoxidase by macrophages promotes atherosclerosis in mice. Circulation 111: 2798-2804, 2005.
160. Metzler KD, Fuchs TA, Nauseef WM, Reumaux D, Roesler J, Schulze I, Wahn V, Papayannopoulos V, and Zychlinsky A. Myeloperoxidase is required for neutrophil extracellular trap formation: implications for innate immunity. Blood 117: 953-959, 2011.

161. Midwinter RG, Vissers MC, and Winterbourn CC. Hypochlorous acid stimulation of the mitogen-activated protein kinase pathway enhances cell survival. Arch Biochem Biophys 394: 13-20, 2001.

162. Miyamoto S, Ronsein GE, Prado FM, Uemi M, Correa TC, Toma IN, Bertolucci A, Oliveira MCB, Motta FD, Medeiros MH, and Di Mascio P. Biological hydroperoxides and singlet molecular oxygen generation. IUBMB Life 59: 322-331, 2007.

163. Mocatta TJ, Pilbrow AP, Cameron VA, Senthilmohan R, Frampton CM, Richards AM, and Winterbourn CC. Plasma concentrations of myeloperoxidase predict mortality after myocardial infarction. J Am Coll Cardiol 49: 1993-2000, 2007.

164. Morgan PE, Laura RP, Maki RA, Reynolds WF, and Davies MJ. Thiocyanate supplementation decreases atherosclerotic plaque in mice expressing human myeloperoxidase. Free Radic Res 49: 743-749, 2015.

165. Morgan PE, Pattison DI, Talib J, Summers FA, Harmer JA, Celermajer DS, Hawkins CL, and Davies MJ. High plasma thiocyanate levels in smokers are a key determinant of thiol oxidation induced by myeloperoxidase. Free Radic Biol Med 51: 1815-1822, 2011.

166. Morris JC. The acid ionization constant of $\mathrm{HOCl}$ from $5^{\circ} \mathrm{C}$ to $35^{\circ} \mathrm{C}$. J Phys Chem 70: 3798-3805, 1966.

167. Nagra RM, Becher B, Tourtellotte WW, Antel JP, Gold D, Paladino T, Smith RA, Nelson JR, and Reynolds WF. Immunohistochemical and genetic evidence of myeloperoxidase involvement in multiple sclerosis. $\mathrm{J} \mathrm{Neu-}$ roimmunol 78: 97-107, 1997.

168. Nagy P, Beal JL, and Ashby MT. Thiocyanate is an efficient endogenous scavenger of the phagocytic killing agent hypobromous acid. Chem Res Toxicol 19: 587-593, 2006.

169. Nagy P, Jameson GN, and Winterbourn CC. Kinetics and mechanisms of the reaction of hypothiocyanous acid with 5-thio-2-nitrobenzoic acid and reduced glutathione. Chem Res Toxicol 22: 1833-1840, 2009.

170. Nauseef WM. Myeloperoxidase in human neutrophil host defence. Cell Microbiol 16: 1146-1155, 2014.

171. Nicholls SJ and Hazen SL. Myeloperoxidase, modified lipoproteins, and atherogenesis. J Lipid Res 50(Suppl): S346-S351, 2009.

172. Noyon C, Delporte C, Dufour D, Cortese M, Rousseau A, Poelvoorde P, Neve J, Vanhamme L, Zouaoui Boudjeltia $\mathrm{K}$, Roumeguere T, and Van Antwerpen P. Validation of a sensitive LC/MSMS method for chloronucleoside analysis in biological matrixes and its applications. Talanta 154: 322-328, 2016.

173. Nussbaum C, Klinke A, Adam M, Baldus S, and Sperandio M. Myeloperoxidase: a leukocyte-derived protagonist of inflammation and cardiovascular disease. Antioxid Redox Signal 18: 692-713, 2013.

174. Nuszkowski A, Grabner R, Marsche G, Unbehaun A, Malle E, and Heller R. Hypochlorite-modified low density lipoprotein inhibits nitric oxide synthesis in endothelial cells via an intracellular dislocalization of endothelial nitric-oxide synthase. J Biol Chem 276: 14212-14221, 2001. 
175. Nybo T, Cai H, Chuang CY, Gamon LF, RogowskaWrzesinska A, and Davies MJ. Chlorination and oxidation of human plasma fibronectin by myeloperoxidase-derived oxidants, and its consequences for smooth muscle cell function. Redox Biol 19: 388-400, 2018.

176. O'Donnell C, Newbold P, White P, Thong B, Stone H, and Stockley RA. 3-Chlorotyrosine in sputum of COPD patients: relationship with airway inflammation. COPD 7: 411-417, 2010.

177. O’Sullivan KM, Lo CY, Summers SA, Elgass KD, McMillan PJ, Longano A, Ford SL, Gan PY, Kerr PG, Kitching AR, and Holdsworth SR. Renal participation of myeloperoxidase in antineutrophil cytoplasmic antibody (ANCA)-associated glomerulonephritis. Kidney Int 88: 1030-1046, 2015.

178. Pan GJ, Rayner BS, Zhang Y, van Reyk DM, and Hawkins CL. A pivotal role for NF-kappaB in the macrophage inflammatory response to the myeloperoxidase oxidant hypothiocyanous acid. Arch Biochem Biophys 642: 23-30, 2018.

179. Panasenko OM, Arnhold J, and Schiller J. Hypochlorite reacts with organic hydroperoxides forming free radicals, but not singlet oxygen, and thus initiates lipid peroxidation. Biochemistry (Mosc) 62: 951-959, 1997.

180. Panasenko OM, Briviba K, Klotz L-O, and Sies $\mathrm{H}$. Oxidative modification and nitration of human lowdensity-lipoproteins by the reaction of hypochlorous acid with nitrite. Arch Biochem Biophys 343: 254-259, 1997.

181. Parker H, Albrett AM, Kettle AJ, and Winterbourn CC. Myeloperoxidase associated with neutrophil extracellular traps is active and mediates bacterial killing in the presence of hydrogen peroxide. J Leukoc Biol 91: 369-376, 2012.

182. Patricio ES, Prado FM, da Silva RP, Carvalho LA, Prates MV, Dadamos T, Bertotti M, Di Mascio P, Kettle AJ, and Meotti FC. Chemical characterization of urate hydroperoxide, a pro-oxidant intermediate generated by urate oxidation in inflammatory and photoinduced processes. Chem Res Toxicol 28: 1556-1566, 2015.

183. Pattison DI and Davies MJ. Absolute rate constants for the reaction of hypochlorous acid with protein sidechains and peptide bonds. Chem Res Toxicol 14: 14531464, 2001.

184. Pattison DI and Davies MJ. A kinetic analysis of the reactions of hypobromous acid with protein components: implications for cellular damage and the use of 3bromotyrosine as a marker of oxidative stress. Biochemistry 43: 4799-4809, 2004.

185. Pattison DI and Davies MJ. Evidence for rapid inter- and intra-molecular chlorine transfer reactions of histamine and carnosine chloramines: implications for the prevention of hypochlorous acid mediated damage. Biochemistry 45: 8152-8162, 2006.

186. Pattison DI and Davies MJ. Reactions of myeloperoxidasederived oxidants with biological substrates: gaining chemical insight into human inflammatory diseases. Curr Med Chem 13: 3271-3290, 2006.

187. Pattison DI, Davies MJ, and Hawkins CL. Reactions and reactivity of myeloperoxidase-derived oxidants: differential biological effects of hypochlorous and hypothiocyanous acids. Free Radic Res 46: 975-995, 2012.

188. Pattison DI, Hawkins CL, and Davies MJ. Hypochlorous acid mediated oxidation of lipid components present in low-density lipoproteins: absolute rate constants, product analysis and computational modeling. Chem Res Toxicol 16: 439-449, 2003.

189. Pattison DI, Hawkins CL, and Davies MJ. Hypochlorous acid-mediated protein oxidation: how important are chloramine transfer reactions and protein tertiary structure? Biochemistry 46: 9853-9864, 2007.

190. Pattison DI, Hawkins CL, and Davies MJ. What are the plasma targets of the oxidant hypochlorous acid? A kinetic modeling approach. Chem Res Toxicol 22: 807-817, 2009.

191. Pennathur S, Bergt C, Shao B, Byan J, Kassim SY, Singh P, Green P, McDonald TO, Brunzell J, Chait A, Oram JF, O'Brien K, Geary RL, and Heinecke J. Human atherosclerotic intima and blood of patients with established coronary artery disease contain high density lipoprotein damaged by reactive nitrogen species. J Biol Chem 279: 42977-42983, 2004.

192. Peskin AV and Winterbourn CC. Kinetics of the reactions of hypochlorous acid and amino acid chloramines with thiols, methionine, and ascorbate. Free Radic Biol Med 30: 572-579, 2001.

193. Peskin AV and Winterbourn CC. Histamine chloramine reactivity with thiol compounds, ascorbate and methionine and with intracellular glutathione. Free Radic Biol Med 35: 1252-1260, 2003.

194. Peskin AV and Winterbourn CC. Taurine chloramine is more selective than hypochlorous acid at targeting critical cysteines and inactivating creatine kinase and glyceraldehyde-3-phosphate dehydrogenase. Free Radic Biol Med 40: 45-53, 2006.

195. Pi JB, Zhang Q, Woods CG, Wong V, Collins S, and Andersen ME. Activation of Nrf2-mediated oxidative stress response in macrophages by hypochlorous acid. Toxicol Appl Pharmacol 226: 236-243, 2008.

196. Pravalika K, Sarmah D, Kaur H, Wanve M, Saraf J, Kalia $\mathrm{K}$, Borah A, Yavagal DR, Dave KR, and Bhattacharya P. Myeloperoxidase and neurological disorder: a crosstalk. ACS Chem Neurosci 9: 421-430, 2018.

197. Prutz WA. Hypochlorous acid interactions with thiols, nucleotides, DNA, and other biological substrates. Arch Biochem Biophys 332: 110-120, 1996.

198. Prutz WA. Interactions of hypochlorous acid with pyrimidine nucleotides, and secondary reactions of chlorinated pyrimidines with GSH, NADH, and other substrates. Arch Biochem Biophys 349: 183-191, 1998.

199. Pullar JM, Winterbourn CC, and Vissers MCM. Loss of GSH and thiol enzymes in endothelial cells exposed to sublethal concentrations of hypochlorous acid. Am J Physiol 277: H1505-H1512, 1999.

200. Rashid I, Maghzal GJ, Chen YC, Cheng D, Talib J, Newington D, Ren M, Vajandar SK, Searle A, Maluenda A, Lindstedt EL, Jabbour A, Kettle AJ, Bongers A, Power C, Michaelsson E, Peter K, and Stocker $\mathrm{R}$. Myeloperoxidase is a potential molecular imaging and therapeutic target for the identification and stabilization of high-risk atherosclerotic plaque. Eur Heart J 39: 33013310, 2018.

201. Ray RS and Katyal A. Myeloperoxidase: bridging the gap in neurodegeneration. Neurosci Biobehav Rev 68: 611620, 2016.

202. Rayner BS, Love DT, and Hawkins CL. Comparative reactivity of myeloperoxidase-derived oxidants with mammalian cells. Free Radic Biol Med 71: 240-255, 2014. 
203. Rayner BS, Zhang Y, Brown BE, Reyes L, Cogger VC, and Hawkins CL. Role of hypochlorous acid ( $\mathrm{HOCl})$ and other inflammatory mediators in the induction of macrophage extracellular trap formation. Free Radic Biol Med 129: 25-34, 2018.

204. Rees MD, Bottle SE, Fairfull-Smith KE, Malle E, Whitelock JM, and Davies MJ. Inhibition of myeloperoxidase-mediated hypochlorous acid production by nitroxides. Biochem J 421: 79-86, 2009.

205. Rees MD and Davies MJ. Heparan sulfate degradation via reductive homolysis of its $\mathrm{N}$-chloro derivatives. $\mathrm{J} \mathrm{Am}$ Chem Soc 128: 3085-3097, 2006.

206. Rees MD, Maiocchi SL, Kettle AJ, and Thomas SR. Mechanism and regulation of peroxidase-catalyzed nitric oxide consumption in physiological fluids: critical protective actions of ascorbate and thiocyanate. Free Radic Biol Med 72: 91-103, 2014.

207. Rees MD, Pattison DI, and Davies MJ. Oxidation of heparan sulphate by hypochlorite: role of N-chloro derivatives and dichloramine-dependent fragmentation. Biochem J 391: 125-134, 2005.

208. Rees MD, Whitelock JM, Malle E, Chuang CY, Iozzo RV, Nilasaroya A, and Davies MJ. Myeloperoxidase-derived oxidants selectively disrupt the protein core of the heparan sulfate proteoglycan perlecan. Matrix Biol 29: 63-73, 2010.

209. Regelmann WE, Schneider LA, Fahrenkrug SC, Gray BH, Johnson S, Herron JM, Clawson CC, Clawson DJ, and Wangensteen OD. Proteinase-free myeloperoxidase increases airway epithelial permeability in a whole trachea model. Pediatr Pulmonol 24: 29-34, 1997.

210. Rensen SS, Bieghs V, Xanthoulea S, Arfianti E, Bakker JA, Shiri-Sverdlov R, Hofker MH, Greve JW, and Buurman WA. Neutrophil-derived myeloperoxidase aggravates non-alcoholic steatohepatitis in low-density lipoprotein receptor-deficient mice. PLoS One 7: e52411, 2012.

211. Reverri EJ, Morrissey BM, Cross CE, and Steinberg FM. Inflammation, oxidative stress, and cardiovascular disease risk factors in adults with cystic fibrosis. Free Radic Biol Med 76: 261-277, 2014.

212. Reynolds WF, Rhees J, Maciejewski D, Paladino T, Sieburg H, Maki RA, and Masliah E. Myeloperoxidase polymorphism is associated with gender specific risk for Alzheimer's disease. Exp Neurol 155: 31-41, 1999.

213. Reynolds WF, Sermet-Gaudelus I, Gausson V, Feuillet MN, Bonnefont JP, Lenoir G, Descamps-Latscha B, and Witko-Sarsat V. Myeloperoxidase promoter polymorphism$463 \mathrm{G}$ is associated with more severe clinical expression of cystic fibrosis pulmonary disease. Mediators Inflamm 2006: 36735, 2006.

214. Ronald JA, Chen JW, Chen Y, Hamilton AM, Rodriguez E, Reynolds F, Hegele RA, Rogers KA, Querol M, Bogdanov A, Weissleder R, and Rutt BK. Enzyme-sensitive magnetic resonance imaging targeting myeloperoxidase identifies active inflammation in experimental rabbit atherosclerotic plaques. Circulation 120: 592-599, 2009.

215. Rudolph TK, Schaper N, Klinke A, Demir C, Goldmann B, Lau D, Koster R, Hellmich M, Meinertz T, Baldus S, and Rudolph V. Liberation of vessel-adherent myeloperoxidase reflects plaque burden in patients with stable coronary artery disease. Atherosclerosis 231: 354-358, 2013.

216. Rudolph V, Andrie RP, Rudolph TK, Friedrichs K, Klinke A, Hirsch-Hoffmann B, Schwoerer AP, Lau D, Fu X,
Klingel K, Sydow K, Didie M, Seniuk A, von Leitner EC, Szoecs K, Schrickel JW, Treede H, Wenzel U, Lewalter T, Nickenig G, Zimmermann WH, Meinertz T, Boger RH, Reichenspurner H, Freeman BA, Eschenhagen T, Ehmke $\mathrm{H}$, Hazen SL, Willems S, and Baldus S. Myeloperoxidase acts as a profibrotic mediator of atrial fibrillation. Nat Med 16: 470-474, 2010.

217. Rudolph V, Goldmann BU, Bos C, Rudolph TK, Klinke A, Friedrichs K, Lau D, Wegscheider K, Haddad M, Meinertz T, and Baldus S. Diagnostic value of MPO plasma levels in patients admitted for suspected myocardial infarction. Int J Cardiol 153: 267-271, 2011.

218. Rymaszewski AL, Tate E, Yimbesalu JP, Gelman AE, Jarzembowski JA, Zhang H, Pritchard KA, Jr., and Vikis HG. The role of neutrophil myeloperoxidase in models of lung tumor development. Cancers (Basel) 6: 1111-1127, 2014.

219. Savenkova MI, Mueller DM, and Heinecke JW. Tyrosyl radical generated by myeloperoxidase is a physiological catalyst for the initiation of lipid-peroxidation in low density lipoprotein. J Biol Chem 269: 20394-20400, 1994.

220. Schieven GL, De Fex H, and Stephenson L. Hypochlorous acid activates tyrosine phosphorylation signal pathways leading to calcium signaling and TNFalpha production. Antioxid Redox Signal 4: 501-507, 2002.

221. Seidel A, Parker H, Turner R, Dickerhof N, Khalilova IS, Wilbanks SM, Kettle AJ, and Jameson GN. Uric acid and thiocyanate as competing substrates of lactoperoxidase. J Biol Chem 289: 21937-21949, 2014.

222. Selemidis S, Dusting GJ, Peshavariya H, Kemp-Harper BK, and Drummond GR. Nitric oxide suppresses NADPH oxidase-dependent superoxide production by S-nitrosylation in human endothelial cells. Cardiovasc Res 75: 349-358, 2007.

223. Senthilmohan R and Kettle AJ. Bromination and chlorination reactions of myeloperoxidase at physiological concentrations of bromide and chloride. Arch Biochem Biophys 445: 235-244, 2006.

224. Shen Y, Ward NC, Hodgson JM, Puddey IB, Wang Y, Zhang D, Maghzal GJ, Stocker R, and Croft KD. Dietary quercetin attenuates oxidant-induced endothelial dysfunction and atherosclerosis in apolipoprotein E knockout mice fed a high-fat diet: a critical role for heme oxygenase-1. Free Radic Biol Med 65: 908-915, 2013.

225. Shiba Y, Kinoshita T, Chuman H, Taketani Y, Takeda E, Kato Y, Naito M, Kawabata K, Ishisaka A, Terao J, and Kawai Y. Flavonoids as substrates and inhibitors of myeloperoxidase: molecular actions of aglycone and metabolites. Chem Res Toxicol 21: 1600-1609, 2008.

226. Siraki AG, Bonini MG, Jiang J, Ehrenshaft M, and Mason RP. Aminoglutethimide-induced protein free radical formation on myeloperoxidase: a potential mechanism of agranulocytosis. Chem Res Toxicol 20: 1038-1045, 2007.

227. Sirpal S. Myeloperoxidase-mediated lipoprotein carbamylation as a mechanistic pathway for atherosclerotic vascular disease. Clin Sci 116: 681-695, 2009.

228. Skaff O, Pattison DI, and Davies MJ. Kinetics of hypobromous acid-mediated oxidation of lipid components and antioxidants. Chem Res Toxicol 20: 1980-1988, 2007.

229. Skaff O, Pattison DI, and Davies MJ. The vinyl ether linkages of plasmalogens are favored targets for myeloperoxidase-derived oxidants: a kinetic study. Biochemistry 47: 8237-8245, 2008. 
230. Skaff O, Pattison DI, and Davies MJ. Hypothiocyanous acid reactivity with low-molecular-mass and protein thiols: absolute rate constants and assessment of biological relevance. Biochem J 422: 111-117, 2009.

231. Skaff O, Pattison DI, Morgan PE, Bachana R, Jain VK, Priyadarsini KI, and Davies MJ. Selenium-containing amino acids are targets for myeloperoxidase-derived hypothiocyanous acid: determination of absolute rate constants and implications for biological damage. Biochem $J$ 441: 305-316, 2012.

232. Slungaard A and Mahoney JR, Jr. Thiocyanate is the major substrate for eosinophil peroxidase in physiologic fluids. Implications for cytotoxicity. J Biol Chem 266: 4903-4910, 1991.

233. Sokolov AV, Ageeva KV, Cherkalina OS, Pulina MO, Zakharova ET, Prozorovskii VN, Aksenov DV, Vasilyev VB, and Panasenko OM. Identification and properties of complexes formed by myeloperoxidase with lipoproteins and ceruloplasmin. Chem Phys Lipids 163: 347-355, 2010.

234. Soubhye J, Aldib I, Delporte C, Prevost M, Dufrasne F, and Van Antwerpen P. Myeloperoxidase as a target for treatment of inflammatory syndromes: mechanisms and structure activity relationships of inhibitors. Curr Med Chem 23: 3975-4008, 2016.

235. Spalteholz H, Panasenko OM, and Arnhold J. Formation of reactive halide species by myeloperoxidase and eosinophil peroxidase. Arch Biochem Biophys 445: 225-234, 2006.

236. Stamp LK, Khalilova I, Tarr JM, Senthilmohan R, Turner R, Haigh RC, Winyard PG, and Kettle AJ. Myeloperoxidase and oxidative stress in rheumatoid arthritis. Rheumatology (Oxford) 51: 1796-1803, 2012.

237. Stocker R, Huang A, Jeranian E, Hou JY, Wu TT, Thomas SR, and Keaney JF, Jr. Hypochlorous acid impairs endothelium-derived nitric oxide bioactivity through a superoxide-dependent mechanism. Arterioscler Thromb Vasc Biol 24: 2028-2033, 2004.

238. Storkey C, Davies MJ, and Pattison DI. Reevaluation of the rate constants for the reaction of hypochlorous acid $(\mathrm{HOCl})$ with cysteine, methionine, and peptide derivatives using a new competition kinetic approach. Free Radic Biol Med 73: 60-66, 2014.

239. Strzepa A, Pritchard KA, and Dittel BN. Myeloperoxidase: a new player in autoimmunity. Cell Immunol 317: $1-8,2017$.

240. Sugiyama S, Kugiyama K, Aikawa M, Nakamura S, Ogawa H, and Libby P. Hypochlorous acid, a macrophage product, induces endothelial apoptosis and tissue factor expression: involvement of myeloperoxidase-mediated oxidant in plaque erosion and thrombogenesis. Arterioscler Thromb Vasc Biol 24: 1309-1314, 2004.

241. Sugiyama S, Okada Y, Sukhova GK, Virmani R, Heinecke JW, and Libby P. Macrophage myeloperoxidase regulation by granulocyte macrophage colony-stimulating factor in human atherosclerosis and implications in acute coronary syndromes. Am J Pathol 158: 879-891, 2001.

242. Summers FA, Forsman Quigley A, and Hawkins CL. Identification of proteins susceptible to thiol oxidation in endothelial cells exposed to hypochlorous acid and N-chloramines. Biochem Biophys Res Commun 425: $157-$ 161, 2012.

243. Takeshita J, Byun J, Nhan TQ, Pritchard DK, Pennathur S, Schwartz SM, Chait A, and Heinecke JW. Myeloperox- idase generates 5-chlorouracil in human atherosclerotic tissue. A potential pathway for somatic mutagenesis by macrophages. J Biol Chem 281: 3096-3104, 2006.

244. Tarr M and Valenzeno DP. Singlet oxygen: the relevance of extracellular production mechanisms to oxidative stress in vivo. Photochem Photobiol Sci 2: 355-361, 2003.

245. Tay A, Tamam Y, Yokus B, Ustundag M, and Orak M. Serum myeloperoxidase levels in predicting the severity of stroke and mortality in acute ischemic stroke patients. Eur Rev Med Pharmacol Sci 19: 1983-1988, 2015.

246. Telles RW, Ferreira GA, da Silva NP, and Sato EI. Increased plasma myeloperoxidase levels in systemic lupus erythematosus. Rheumatol Int 30: 779-784, 2010.

247. Teng N, Maghzal GJ, Talib J, Rashid I, Lau AK, and Stocker R. The roles of myeloperoxidase in coronary artery disease and its potential implication in plaque rupture. Redox Rep 22: 51-73, 2017.

248. Thomas EL, Grisham MB, and Jefferson MM. Cytotoxicity of chloramines. Methods Enzymol 132: 585-593, 1986.

249. Thomas EL, Grisham MB, and Jefferson MM. Preparation and characterization of chloramines. Methods Enzymol 132: 569-585, 1986.

250. Thomson E, Brennan S, Senthilmohan R, Gangell CL, Chapman AL, Sly PD, Kettle AJ, Australian Respiratory Early Surveillance Team for Cystic F, Balding E, Berry LJ, Carlin JB, Carzino R, de Klerk N, Douglas T, Foo C, Garratt LW, Hall GL, Harrison J, Kicic A, Laing IA, Logie KM, Massie J, Mott LS, Murray C, Parsons F, Pillarisetti N, Poreddy SR, Ranganathan SC, Robertson CF, Robins-Browne R, Robinson PJ, Skoric B, Stick SM, Sutanto EN, and Williamson E. Identifying peroxidases and their oxidants in the early pathology of cystic fibrosis. Free Radic Biol Med 49: 1354-1360, 2010.

251. Thukkani AK, Albert CJ, Wildsmith KR, Messner MC, Martinson BD, Hsu FF, and Ford DA. Myeloperoxidasederived reactive chlorinating species from human monocytes target plasmalogens in low density lipoprotein. J Biol Chem 278: 36365-36372, 2003.

252. Tian R, Ding Y, Peng YY, and Lu N. Inhibition of myeloperoxidase- and neutrophil-mediated hypochlorous acid formation in vitro and endothelial cell injury by (-)epigallocatechin gallate. J Agric Food Chem 65: 31983203, 2017.

253. Tiden AK, Sjogren T, Svensson M, Bernlind A, Senthilmohan R, Auchere F, Norman H, Markgren PO, Gustavsson S, Schmidt S, Lundquist S, Forbes LV, Magon NJ, Paton LN, Jameson GN, Eriksson H, and Kettle AJ. 2Thioxanthines are mechanism-based inactivators of myeloperoxidase that block oxidative stress during inflammation. J Biol Chem 286: 37578-37589, 2011.

254. Tien M. Myeloperoxidase-catalyzed oxidation of tyrosine. Arch Biochem Biophys 367: 61-66, 1999.

255. Tiyerili V, Camara B, Becher MU, Schrickel JW, Lutjohann D, Mollenhauer M, Baldus S, Nickenig G, and Andrie RP. Neutrophil-derived myeloperoxidase promotes atherogenesis and neointima formation in mice. Int $J$ Cardiol 204: 29-36, 2016.

256. Trepanier DJ and Thibert RJ. Carbamylation of erythrocyte membrane aminophospholipids: an in vitro and in vivo study. Clin Biochem 29: 333-345, 1996. 
257. Tsimikas S. Oxidative biomarkers in the diagnosis and prognosis of cardiovascular disease. Am J Cardiol 98: 9P17P, 2006.

258. Tzikas S, Schlak D, Sopova K, Gatsiou A, Stakos D, Stamatelopoulos K, Stellos K, and Laske C. Increased myeloperoxidase plasma levels in patients with Alzheimer's disease. J Alzheimers Dis 39: 557-564, 2014.

259. Ullen A, Fauler G, Bernhart E, Nusshold C, Reicher H, Leis HJ, Malle E, and Sattler W. Phloretin ameliorates 2chlorohexadecanal-mediated brain microvascular endothelial cell dysfunction in vitro. Free Radic Biol Med 53: 1770-1781, 2012.

260. Undurti A, Huang Y, Lupica JA, Smith JD, DiDonato JA, and Hazen SL. Modification of high density lipoprotein by myeloperoxidase generates a pro-inflammatory particle. J Biol Chem 284: 30825-30835, 2009.

261. Urban CF, Ermert D, Schmid M, Abu-Abed U, Goosmann C, Nacken W, Brinkmann V, Jungblut PR, and Zychlinsky A. Neutrophil extracellular traps contain calprotectin, a cytosolic protein complex involved in host defense against Candida albicans. PLoS Pathog 5: e1000639, 2009.

262. van Dalen CJ and Kettle AJ. Substrates and products of eosinophil peroxidase. Biochem J 358: 233-239, 2001.

263. van Dalen CJ, Whitehouse MW, Winterbourn CC, and Kettle AJ. Thiocyanate and chloride as competing substrates for myeloperoxidase. Biochem J 327: 487-492, 1997.

264. van Dalen CJ, Winterbourn CC, Senthilmohan R, and Kettle AJ. Nitrite as a substrate and inhibitor of myeloperoxidase. Implications for nitration and hypochlorous acid production at sites of inflammation. J Biol Chem 275: 11638-11644, 2000.

265. van der Veen BS, de Winther MP, and Heeringa P. Myeloperoxidase: molecular mechanisms of action and their relevance to human health and disease. Antioxid Redox Signal 11: 2899-2937, 2009.

266. van der Vliet A, Nguyen MN, Shigenaga MK, Eiserich JP, Marelich GP, and Cross CE. Myeloperoxidase and protein oxidation in cystic fibrosis. Am J Physiol Lung Cell Mol Physiol 279: L537-L546, 2000.

267. Van der Zwan LP, Scheffer PG, Dekker JM, Stehouwer CD, Heine RJ, and Teerlink T. Hyperglycemia and oxidative stress strengthen the association between myeloperoxidase and blood pressure. Hypertension 55: 1366-1372, 2010.

268. Vasu VT, de Cruz SJ, Houghton JS, Hayakawa KA, Morrissey BM, Cross CE, and Eiserich JP. Evaluation of thiol-based antioxidant therapeutics in cystic fibrosis sputum: focus on myeloperoxidase. Free Radic Res 45: 165-176, 2011.

269. Vissers MC, Carr AC, and Chapman AL. Comparison of human red cell lysis by hypochlorous and hypobromous acids: insights into the mechanism of lysis. Biochem $J$ 330: 131-138, 1998.

270. Vissers MC, Carr AC, and Winterbourn CC. Fatty acid chlorohydrins and bromohydrins are cytotoxic to human endothelial cells. Redox Rep 6: 49-55, 2001.

271. Vissers MC, Lee WG, and Hampton MB. Regulation of apoptosis by vitamin C. Specific protection of the apoptotic machinery against exposure to chlorinated oxidants. J Biol Chem 276: 46835-46840, 2001.

272. Vissers MC and Winterbourn CC. Oxidation of intracellular glutathione after exposure of human red blood cells to hypochlorous acid. Biochem J 307: 57-62, 1995.

273. Vissers MCM, Pullar JM, and Hampton MB. Hypochlorous acid causes caspase activation and apoptosis or growth arrest in human endothelial cells. Biochem $J$ 344: 443-449, 1999.

274. Vita JA, Brennan M-L, Gokce N, Mann SA, Goormastic M, Shishehbor MH, Penn MS, Keaney JF, Jr., and Hazen SL. Serum myeloperoxidase levels independently predict endothelial dysfunction in humans. Circulation 110: 1134-1139, 2004.

275. Wang JG, Mahmud SA, Nguyen J, and Slungaard A. Thiocyanate-dependent induction of endothelial cell adhesion molecule expression by phagocyte peroxidases: a novel HOSCN-specific oxidant mechanism to amplify inflammation. J Immunol 177: 8714-8722, 2006.

276. Wang JG, Mahmud SA, Thompson JA, Geng JG, Key NS, and Slungaard A. The principal eosinophil peroxidase product, HOSCN, is a uniquely potent phagocyte oxidant inducer of endothelial cell tissue factor activity: a potential mechanism for thrombosis in eosinophilic inflammatory states. Blood 107: 558-565, 2006.

277. Wang Q, Xie Z, Zhang W, Zhou J, Wu Y, Zhang M, Zhu $\mathrm{H}$, and Zou MH. Myeloperoxidase deletion prevents highfat diet-induced obesity and insulin resistance. Diabetes 63: 4172-4185, 2014.

278. Wang W, Jian Z, Guo J, and Ning X. Increased levels of serum myeloperoxidase in patients with active rheumatoid arthritis. Life Sci 117: 19-23, 2014.

279. Wang Y, Rosen H, Madtes DK, Shao B, Martin TR, Heinecke JW, and $\mathrm{Fu} \mathrm{X}$. Myeloperoxidase inactivates TIMP-1 by oxidizing its N-terminal cysteine residue: an oxidative mechanism for regulating proteolysis during inflammation. J Biol Chem 282: 31826-31834, 2007.

280. Wang Z, Nicholls SJ, Rodriguez ER, Kummu O, Horkko S, Barnard J, Reynolds WF, Topol EJ, DiDonato JA, and Hazen SL. Protein carbamylation links inflammation, smoking, uremia and atherogenesis. Nat Med 13: 1176-1184, 2007.

281. Ward J, Spath SN, Pabst B, Carpino PA, Ruggeri RB, Xing G, Speers AE, Cravatt BF, and Ahn K. Mechanistic characterization of a 2-thioxanthine myeloperoxidase inhibitor and selectivity assessment utilizing click chemistry-activity-based protein profiling. Biochemistry 52: 9187-9201, 2013.

282. Wei Y, Liu XM, Peyton KJ, Wang H, Johnson FK, Johnson RA, and Durante W. Hypochlorous acid-induced heme oxygenase-1 gene expression promotes human endothelial cell survival. Am J Physiol Cell Physiol 297: C907-C915, 2009.

283. Weitzman SA and Gordon LI. Inflammation and cancer: role of phagocyte-generated oxidants in carcinogenesis. Blood 76: 655-663, 1990.

284. Whiteman M, Chu SH, Siau JL, Rose P, Sabapathy K, Schantz JT, Cheung NS, Spencer JP, and Armstrong JS. The pro-inflammatory oxidant hypochlorous acid induces Bax-dependent mitochondrial permeabilisation and cell death through AIF-/EndoG-dependent pathways. Cell Signal 19: 705-714, 2007.

285. Whiteman M, Jenner A, and Halliwell B. Hypochlorous acid-induced base modifications in isolated calf thymus DNA. Chem Res Toxicol 10: 1240-1246, 1997.

286. Whiteman M, Rose P, Siau JL, and Halliwell B. Nitritemediated protection against hypochlorous acid-induced chondrocyte toxicity: a novel cytoprotective role of nitric oxide in the inflamed joint? Arthritis Rheum 48: 31403150, 2003.

287. Whiteman M, Siau JL, and Halliwell B. Lack of tyrosine nitration by hypochlorous acid in the presence of physi- 
ological concentrations of nitrite. Implications for the role of nitryl chloride in tyrosine nitration in vivo. $\mathrm{J} \mathrm{Biol} \mathrm{Chem}$ 278: 8380-8384, 2003.

288. Whiteman M, Spencer JPE, Szeto HH, and Armstrong JS. Do mitochondriotropic antioxidants prevent chlorinative stress-induced mitochondrial and cellular injury? Antioxid Redox Signal 10: 641-650, 2008.

289. Winterbourn CC. Comparative reactivities of various biological compounds with myeloperoxidase-hydrogen peroxide-chloride, and similarity of the oxidant to hypochlorite. Biochim Biophys Acta 840: 204-210, 1985.

290. Winterbourn CC. Biological reactivity and biomarkers of the neutrophil oxidant, hypochlorous acid. Toxicology 181-182: 223-227, 2002.

291. Winterbourn CC, Hampton MB, Livesey JH, and Kettle AJ. Modeling the reactions of superoxide and myeloperoxidase in the neutrophil phagosome: implications for microbial killing. J Biol Chem 281: 39860-39869, 2006.

292. Winterbourn CC and Kettle AJ. Redox reactions and microbial killing in the neutrophil phagosome. Antioxid Redox Signal 18: 642-660, 2013.

293. Woods CG, Fu J, Xue P, Hou Y, Pluta LJ, Yang L, Zhang Q, Thomas RS, Andersen ME, and Pi J. Dose-dependent transitions in Nrf2-mediated adaptive response and related stress responses to hypochlorous acid in mouse macrophages. Toxicol Appl Pharmacol 238: 27-36, 2009.

294. Xu Y, Szep S, and Lu Z. The antioxidant role of thiocyanate in the pathogenesis of cystic fibrosis and other inflammation-related diseases. Proc Natl Acad Sci U S A 106: 20515-20519, 2009.

295. Yang WJ, Wang MY, Pan FZ, Shi C, and Cen H. Association between MPO-463G > A polymorphism and cancer risk: evidence from 60 case-control studies. World J Surg Oncol 15: 144, 2017.

296. Yang YT, Whiteman M, and Gieseg SP. HOCl causes necrotic cell death in human monocyte derived macrophages through calcium dependent calpain activation. Biochim Biophys Acta 1823: 420-429, 2012.

297. Yang YT, Whiteman M, and Gieseg SP. Intracellular glutathione protects human monocyte-derived macrophages from hypochlorite damage. Life Sci 90: 682-688, 2012.

298. Yap YW, Chen MJ, Choy MS, Peng ZF, Whiteman M, Manikandan J, Melendez AJ, and Cheung NS. Temporal transcriptomic profiling reveals cellular targets that govern survival in HOCl-mediated neuronal apoptosis. Life Sci 87: 457-467, 2010.

299. Yap YW, Whiteman M, Bay BH, Li Y, Sheu FS, Qi RZ, Tan $\mathrm{CH}$, and Cheung NS. Hypochlorous acid induces apoptosis of cultured cortical neurons through activation of calpains and rupture of lysosomes. J Neurochem 98: 1597-1609, 2006.

300. Yu G, Liang Y, Huang Z, Jones DW, Pritchard KA, Jr., and Zhang $\mathrm{H}$. Inhibition of myeloperoxidase oxidant production by $\mathrm{N}$-acetyl lysyltyrosylcysteine amide reduces brain damage in a murine model of stroke. $J$ Neuroinflammation 13: 119, 2016.

301. Zederbauer M, Furtmueller PG, Brogioni S, Jakopitsch C, Smulevich G, and Obinger C. Heme to protein linkages in mammalian peroxidases: impact on spectroscopic, redox and catalytic properties. Nat Prod Rep 24: 571-584, 2007.

302. Zeng $\mathbf{J}$ and Fenna RE. X-ray crystal structure of canine myeloperoxidase at 3 A resolution. J Mol Biol 226: 185207, 1992.
303. Zhang C, Patel R, Eiserich JP, Zhou F, Kelpke S, Ma W, Parks DA, Darley Usmar V, and White CR. Endothelial dysfunction is induced by proinflammatory oxidant $\mathrm{HOCl}$. Am J Physiol 281: H1469-H1475, 2001.

304. Zhang C, Yang J, and Jennings LK. Leukocyte-derived myeloperoxidase amplifies high-glucose-induced endothelial dysfunction through interaction with high-glucose-stimulated, vascular non-leukocyte-derived reactive oxygen species. Diabetes 53: 2950-2959, 2004.

305. Zhang H, Jing X, Shi Y, Xu H, Du J, Guan T, Weihrauch D, Jones DW, Wang W, Gourlay D, Oldham KT, Hillery CA, and Pritchard KA, Jr. N-acetyl lysyltyrosylcysteine amide inhibits myeloperoxidase, a novel tripeptide inhibitor. J Lipid Res 54: 3016-3029, 2013.

306. Zhang H, Ray A, Miller NM, Hartwig D, Pritchard KA, and Dittel BN. Inhibition of myeloperoxidase at the peak of experimental autoimmune encephalomyelitis restores blood-brain barrier integrity and ameliorates disease severity. J Neurochem 136: 826-836, 2016.

307. Zhang H, Xu H, Weihrauch D, Jones DW, Jing X, Shi Y, Gourlay D, Oldham KT, Hillery CA, and Pritchard KA, Jr. Inhibition of myeloperoxidase decreases vascular oxidative stress and increases vasodilatation in sickle cell disease mice. J Lipid Res 54: 3009-3015, 2013.

308. Zhang R, Brennan ML, Fu X, Aviles RJ, Pearce GL, Penn MS, Topol EJ, Sprecher DL, and Hazen SL. Association between myeloperoxidase levels and risk of coronary artery disease. J Am Med Assoc 286: 2136-2142, 2001.

309. Zhang R, Shen Z, Nauseef WM, and Hazen SL. Defects in leukocyte-mediated initiation of lipid peroxidation in plasma as studied in myeloperoxidase-deficient subjects: systematic identification of multiple endogenous diffusible substrates for myeloperoxidase in plasma. Blood 99: 1802-1810, 2002.

310. Zheng L, Nukuna B, Brennan ML, Sun M, Goormastic M, Settle M, Schmitt D, Fu X, Thomson L, Fox PL, Ischiropoulos H, Smith JD, Kinter M, and Hazen SL. Apolipoprotein A-I is a selective target for myeloperoxidasecatalyzed oxidation and functional impairment in subjects with cardiovascular disease. J Clin Invest 114: 529-541, 2004.

311. Zhou B, Zu L, Chen Y, Zheng X, Wang Y, Pan B, Dong M, Zhou E, Zhao M, Zhang Y, Zheng L, and Gao W. Myeloperoxidase-oxidized high density lipoprotein impairs atherosclerotic plaque stability by inhibiting smooth muscle cell migration. Lipids Health Dis 16: 3, 2017.

Address correspondence to: Prof. Clare L. Hawkins

Department of Biomedical Sciences Panum Institute

University of Copenhagen Blegdamsvej $3 B$

DK-2200 Copenhagen $N$ Denmark

E-mail: clare.hawkins@sund.ku.dk

Date of first submission to ARS Central, January 10, 2020; date of acceptance, January 18, 2020. 


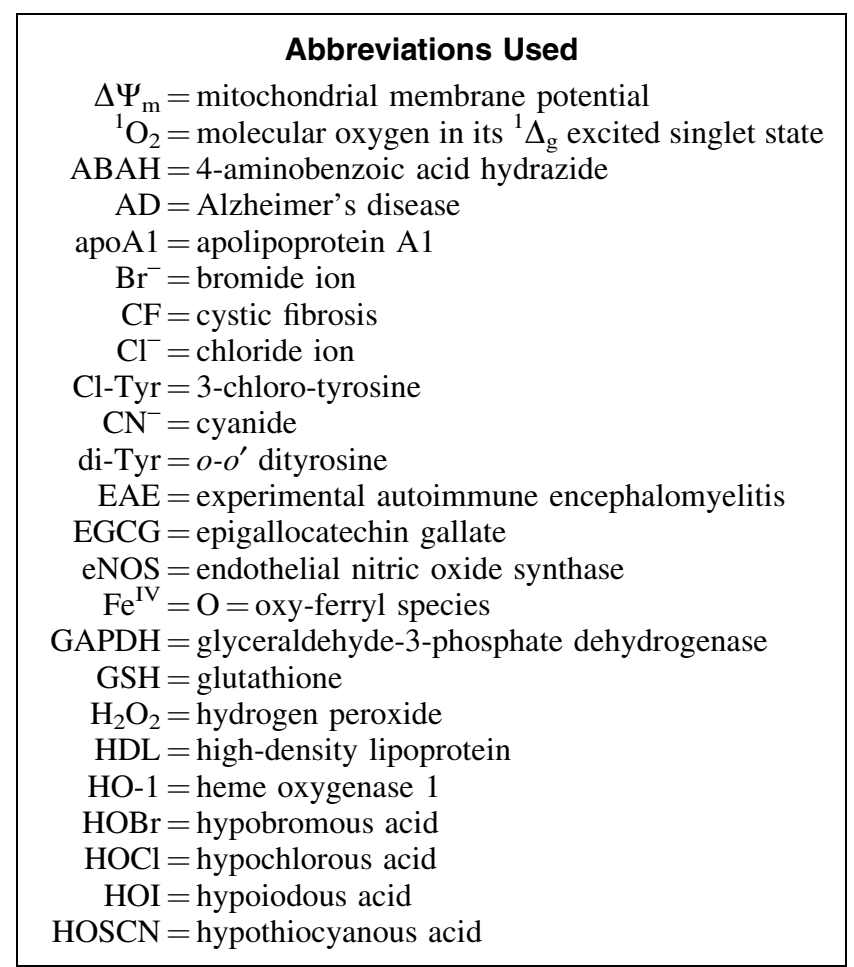

$\mathrm{KYC}=N$-acetyl lysyltyrosylcysteine amide

$\mathrm{LDL}=$ low-density lipoprotein

$\mathrm{MMP}=$ matrix metalloproteinase

$\mathrm{MPO}=$ myeloperoxidase

$\mathrm{MS}=$ multiple sclerosis

NETs $=$ neutrophil extracellular traps

$\mathrm{NO}^{\bullet}=$ nitric oxide radical

$\mathrm{NO}_{2}{ }^{-}=$nitrite ion

$\mathrm{NO}_{2} \mathrm{Cl}=$ nitryl chloride

$\mathrm{Nrf} 2=$ nuclear factor erythroid 2-related factor 2

$\mathrm{O}_{2}{ }^{\bullet-}=$ superoxide radical anion

$\mathrm{OCN}^{-}=$cyanate

$\mathrm{ONOOH}=$ peroxynitrous acid

$\mathrm{PD}=$ Parkinson's disease

$\mathrm{RS}-\mathrm{Cl}=$ sulfenyl chloride

$\mathrm{RSOH}=$ sulfenic acid

$\mathrm{RSO}_{2} \mathrm{H}=$ sulfinic acid

$\mathrm{RSO}_{3} \mathrm{H}=$ sulfonic acid

$\mathrm{SCN}^{-}=$thiocyanate ions

$(\mathrm{SCN})_{2}=$ thiocyanogen

$\mathrm{Sec}=$ selenocysteine

$\mathrm{SOD}=$ superoxide dismutase

$\mathrm{SR}=$ sarco/endoplasmic reticulum

$\operatorname{TrxR}=$ thioredoxin reductase

$\mathrm{VSMC}=$ vascular smooth muscle cells 